\title{
Wounaan Storying as Intervention: Storywork in the Crafting of a Multimodal Illustrated Story Book on People and Birds
}

\author{
Rito Ismare Peña ${ }^{1}$, Chenier Carpio Opua ${ }^{1}$, Doris Cheucarama Membache ${ }^{1}$, Frankie Grin ${ }^{2}$, \\ Dorindo Membora Peña ${ }^{1}$, Chindío Peña Ismare ${ }^{1}$ and Julie Velásquez Runk ${ }^{3,4, *}$ \\ 1 Wounaan Podpa Nım Pömaa, Panama City, Panama; caciquewoun.4@gmail.com (R.I.P.); \\ cheniercarpio@hotmail.com (C.C.O.); dorischm79@hotmail.com (D.C.M.); \\ dorindo.membora@gmail.com (D.M.P.); bertismare_79@yahoo.es (C.P.I.) \\ 2 Independent Researcher, Atlanta, GA 30032, USA; frankiegrin.ar@@gmail.com \\ 3 Department of Anthropology, University of Georgia, Athens, GA 30602, USA \\ 4 Smithsonian Tropical Research Institute, Panama City, Panama \\ * Correspondence: julievr@uga.edu
}

check for updates

Citation: Ismare Peña, Rito, Chenier Carpio Opua, Doris Cheucarama Membache, Frankie Grin, Dorindo Membora Peña, Chindío Peña Ismare, and Julie Velásquez Runk. 2021. Wounaan Storying as Intervention: Storywork in the Crafting of a Multimodal Illustrated Story Book on People and Birds. Genealogy 5: 91. https: / / doi.org/10.3390/ genealogy5040091

Received: 7 June 2021

Accepted: 14 September 2021

Published: 21 October 2021

Publisher's Note: MDPI stays neutral with regard to jurisdictional claims in published maps and institutional affiliations.

Copyright: (c) 2021 by the authors. Licensee MDPI, Basel, Switzerland. This article is an open access article distributed under the terms and conditions of the Creative Commons Attribution (CC BY) license (https:// creativecommons.org/licenses/by/ $4.0 /)$.

\begin{abstract}
A growing body of scholarship addresses what Indigenous peoples have always known: stories are critically important to who we are and how to be in the world. For Wounaan, an Indigenous people of Panama and Colombia, ancestors' stories are no longer frequently told. As part of the Wounaan Podpa Nım Pömaam (National Wounaan Congress) and Foundation for the Development of Wounaan People's project on bird guiding, birds and culture, and forest restoration in Panama, we leveraged the publication requirement as political intervention and anticolonial practice in storying worlds. This article is the story of our storying, the telling and crafting of an illustrated story book that honors Wounaan convivial lifeworlds, Wounaan chaain döhigaau nemchaain hoo wënı rrajim/Los niños wounaan, en sus aventuras vieron muchas aves/The Adventures of Wounaan Children and Many Birds. Here, we have used video conference minutes and recordings, voice and text messages, emails, recollections, and a conference co-presentation to show stories as Indigenous method and reality, as epistemological and ontological. We use a narrative form to weave together our collaborative process and polish the many storying decisions on relationality, time, egalitarianism, movement, rivers, embodiment, and verbal poetics through an everyday adventure of siblings and birds. Available as a multimodal illustrated story book in digital audio and print, we conclude by advocating for new media to further storying Indigenous lifeworlds.
\end{abstract}

Keywords: Wounaan; Indigenous; conviviality; egalitarianism; movement; temporality; weaving; polishing; land; waters

\section{Storying}

This is the story of a story based on stories. As part of the Indigenous Wounaan authorities' (Wounaan Podpa Nım Pömaam (National Wounaan Congress) and Foundation for the Development of Wounaan People) projects on people, birds, and sustainability in Panama, we leveraged the publication requirement as political intervention and anticolonial practice in storying worlds. We knew, as co-author Chindío Peña Ismare (CPI) has said, "that the Wounaan world has changed a lot ... some practices have already been forgotten, even the forms, the words, the meaning of words ... already today's youth have forgotten" and wanted to value, honor, and respect Wounaan lifeworlds with a book for children. This article, this story, is our storying, our crafting of a multimodal (print and digital audio) illustrated story book based on Wounaan stories. Originally written in Wounaan meu (the Wounaan language), we translated Wounaan chaain döhigaau nemchaain hoo wënı rrajim into Spanish and English, and Frankie Grin (FG) translated the narrative into paintings with our collaboration. "It seems important," CPI expressed, "that the book highlights 
these experiences that are from the past, but also in some places that are still reflected and practiced."

Indigenous stories, storytelling, and storying (the simultaneous telling and crafting of stories) are crucial to being and belonging in the world. As Kovach $(2009$, p. 94) has written:

"Stories remind us of who we are and of our belonging. Stories hold within them knowledges while simultaneously signifying relationships ... stories can never be decontextualized from the teller. They are active agents within a relational world, pivotal in gaining insight into a phenomenon. Oral stories are born of connections within the world, and are thus recounted relationally. They tie us with our past and provide a basis for continuity with future generations."

This, too, is our experience with stories.

Across the American continent, as North and South America are referred to in Spanish as singular, there is widespread recognition of the importance of stories to First Nations, Native American, and Indigenous or Original peoples. The growing scholarship in English on stories and storywork as an Indigenous and decolonizing method (e.g., Archibald 2008; Denzin et al. 2008; Smith 2002; Windchief and Pedro 2019) is nascent in Spanish and Portuguese with relatively little attention to stories (e.g., Micarelli 2018; Ramos 2019; Rocha-Buelvas and Ruíz-Lurduy 2018). That may because throughout Latin America or Abya Yala/Abiayala (both problematic epistemological terms), stories and storytelling are foundational to Mesoamerican pictorial codices, Indigenous chroniclers of Spanish colonization, Indigenous stories still told, historic witness accounts known as testimonios $\mathrm{S}$, picturebooks, and the fluorescence of Indigenous literature, media and movies, and others. As Arias (2018) has noted, grassroots Indigenous scholars in the region often work outside the academy, and are knowledge producers as well as political actors (Perry and Rappaport 2013). These characteristics often mean that publications are local and national, have small print runs, and remain un- or under-indexed on search engines based in the Global North Despite this, and thanks to the growth of open-access digital publishing, many examples of Indigenous storywork exist, such as the wonderful Tseltal print and audio book Sjalel Kibeltik Sts'isjel Ja Kechtiki' (Köhler et al. 2010). Still, it also remains common for stories to be treated as windows into cosmovision (rather than ontology), as oral traditions removed from relationality and set against written work (Martínez this volume), or even as legend or mythical entertainment.

\section{Indigenous Methods in the Relational Conviviality of People and Birds}

"And this pëp'amie ${ }^{\mathrm{W}}[$ tricas , squirrel cuckoo] alerts of good and bad news. The good news is when it is repeatedly singing "tris ... tris, tris ... tris ... tris, tris" then it is informing of good news. If one is hunting, it [means that one] may be effective with the animal. And, the song of 'wihjẽer' is negative. It is bad news. Repeatedly singing, 'tris, tris, wihjẽer ... tris, tris, wihjẽer' there is news, but bad ... And, if [the message] may be for [good] luck, it also [may] be for bad [luck]. You see an animal, but never kill it. So, 'tris, tris' is like giving notice." Hapk' $\Lambda \Lambda n^{\mathrm{W} 1}$ Rito Ismare Peña, December 2017.

For Wounaan, birds are part of the convivial relationality of life: they are among the many beings of land and waters with which one respects and lives. Wounaan stories (jöoingarm nem higgk'aa ${ }^{\mathrm{W}}$ ), often referred to in Spanish as ancestors' stories, tell of the features and behavior of the people that became animals, including birds. They communicate and inspire. Once people, birds move between the sky and the earth, they are messengers whose songs alert about the present and future, and the people know the songs meanings. Birds' colors, patterns, behavior, and forms also inspire. Their virtuous characteristics are passed to newborns in chaai $p^{\prime}$ oo $n_{\Lambda} m^{\mathrm{W}}$ (ombligado ${ }^{\mathrm{S}}$ or naveling). Their play (jemk'a $t_{\Lambda} n \Lambda m^{\mathrm{W}}$ ) is imitated in dance $\left(j e m k^{\prime} a n_{\Delta} m^{\mathrm{W}}\right.$ ), accompanied by $p^{\prime} i p^{\prime} a n^{\mathrm{W}}$ (three-holed flute) and tamburr $\mathrm{W}$ (drum) music that characterizes the birds and resonates across space in shared experience. The Wounaan meu word for bird is that for animal, nemchaai ${ }^{\mathrm{W}}$; it is only by context that one knows whether one is referring to (what in English and Spanish is) a bird or an animal. If there is no context, the primary meaning of nemchaai is bird. 
Panama's Indigenous Wounaan authorities, the Wounaan Podpa Nım Pömaam (WPNP) and its sibling non-governmental organization, the Fundación para el Desarrollo del Pueblo Wounaan (FUNDEPW, Foundation for the Development of Wounaan People), began the first of two community-based grants in 2017. Working with the community of Puerto Lara and then with the communities of Río Hondo and Río Platanares, the projects aimed to develop intercultural bird guiding, value and revitalize Wounaan relationships with birds, create community ecotourism agreements, and restore forests. These projects were developed by the WPNP and the FUNDEPW, beginning as synergistic conversations with Marsha Kellogg (MK), Janice Jorgensen, and Robert Mesta of the ally organization Native Future (NF) in 2016. The ideas were presented and talked about with all of Panama's Wounaan communities, first at the 2017 and again at the 2019 Wounaan national congress, with the plenaries' approvals to move forward. The funding came later, through the Small Grants Program of the United Nations Development Program and Global

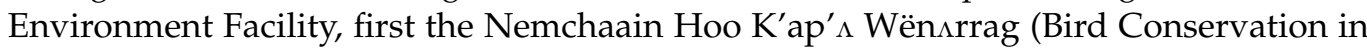
Puerto Lara) and then Nemchaain $\mathrm{T}^{\prime} \Lambda$ Waiwen $\Lambda$ rrag (Conservation of Wounaan Birds). We are the cultural team (Wounaan hãba $p^{\prime}$ itk'atarr $k^{\prime} \Lambda \Lambda n^{\mathrm{W}}$ or equipo cultural Wounaan ${ }^{\mathrm{S}}$ ) on those projects: hapk' $\Lambda \Lambda n$ Rito Ismare Peña (RIP), Chenier Carpio Opua (CCO), Doris Cheucarama Membache (DCM), Dorindo Membora Peña (DMP), and Chindío Peña Ismare (CPI) are Wounaan, and Julie Velásquez Runk (JVR) and Frankie Grin (FG) are Euro-American and Latinx with Indigenous heritage who we invited to work with us. FG joined us in 2020 to work on illustrations and DMP joined the team later that same year. We share respect for Wounaan lifeworlds and responsibility to address them as Wounaan see fit, sustaining commitments to Indigenous language, cultural revitalization, and resurgence by making our work relevant for Wounaan communities (Ismare Peña 2011; Peña 2009; Peña Ismare 1997; Peña Ismare et al. 2019; Velásquez Runk and Opua 2018; Velásquez Runk 2020a).

Our co-work was thus part of the larger collaborations of the WPNP, FUNDEPW, and Wounaan communities. Before the sequential small grants were initiated, WPNP and FUNDEPW held 3-day community consent consultations in Puerto Lara in July 2017 and in Río Hondo about two years later. RIP, DCM, and CCO regularly joined those rural Wounaan communities in the monthly bird guiding and identification workshops and JVR was there for two. CCO and RIP also participated in the project's community festivals/meetings, and DCM led a Wounaan meu workshop on the first project. We were working to better integrate the bird and forest restoration activities on the second grant when the pandemic curtailed our in-person work together in communities.

In ecology, environmental studies, and anthropology, there is renewed attention to birds among people, including work throughout Latin America and beyond. Some of this work is explicitly ethno-ornithological, often separating birds from other relationships and with a more descriptive focus (e.g., de Freitas and Pasa 2011; Ibarra and Pizarro 2016; Medrano et al. 2017; Sarmiento 2010; Sault 2020; Tidemann and Gosler 2010; VásquezDávila 2014; Wyndham and Park 2018), and some is more ontological, addressing birds as part of the reality of lifeworlds (Clarke 2016; Dove 1993; Kane 2015; Martínez Mauri et al. 2014; Medrano 2017; Simon 2020; Watts 2013). In some work, such as our own, nonIndigenous bird watchers supported research, unintentionally strengthening an outside gaze: enumerating species, developing lists of their local names, and recording their roles in cultures. This approach allows researchers and communities a ready organizing principle and to work through published bird field guides. In our first project, from late 2017-2019, we saw how ally individuals, organizations, and even our bird guide instructor unintentionally facilitated this perspective. Significantly, we recognized that it reduced multisensory entangled relationality-often called conviviality in Spanish—that is foundational to Wounaan life in maach durrW (Wounaan territory/nation) (Peña 2009; Peña Ismare et al. 2020; Velásquez Runk et al. 2016). We struggled with that outsider gaze on our first project and committed ourselves to undoing more of it for the second project.

Our objective on these projects was to value and respect Wounaan lifeworlds by creating materials in Wounaan meu for Wounaan. We have wanted to make materials that 
are relevant for children because of the multiple changes that are diminishing Wounaan language and knowing/doing: formal education in non-Indigenous thought in Spanish (including rural and urban schools and higher education), capitalist expansion and wage labor, continued settler colonialism and natural resource extraction in Indigenous lands, and outmigration from rural communities (Peña Ismare 2006; Velásquez Runk 2012). Now that there have been three generations educated in the government's schools, in some rural communities and in most urban areas, children are becoming Spanish dominant. We have been particularly concerned about adoption of Spanish grammar into Wounaan meu. "Our children," DMP said, "already are forgetting our culture; the children, the generation of today, they are forgetting a lot ... and it worries me." Government schools provide no materials in the Wounaan language or any specifics about Wounaan lifeworlds, even though Articles 83 and 85 of the 1972 Constitution indicate support for Indigenous intercultural bilingual education and material, social, and spiritual values and Law 88 of 2010 is to support intercultural, bilingual education (Velásquez Runk 2012). When required to make a book to culminate the second grant, we were determined to make a publication for children; we knew that it would be a challenge to do so because our budget was not increased for the requisite.

As we have long done, we use the Indigenous methods of collaborative doing and knowing. Aside from FG, we have lived years in rural and urban Wounaan communities, and early on we abandoned doing interviews to write what we already knew/experienced. We repeatedly met together to co-create: brainstorming, walking, conversing, discussing, birding, working (Figure 1). We used this approach to research as anticolonial practice, one based, as CCO said, on that of Wounaan community meetings, in which "consensus is sought and doing it collectively ... culturally that concept is maintained." In our meetings, we unconsciously modified the sociality, relationality, fluidity, sharing, and morality/caretaking of collaborative community work (Velásquez Runk 2014). That knowing and doing is in itself convivial wellbeing and care, characterized by trilingual wordplaying, recollecting, encouraging, asking, storytelling, food sharing, joking. It is punctuated by taking what we do to share and discuss with the plenary of a Wounaan national congress, much as we join there with others to embody birds dancing, their (and our) character resonating through the flute notes and drum beat. The joyful spirit of our approach is accentuated by the recent work addressing research as ceremony and

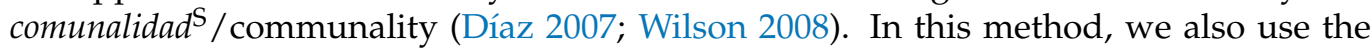
repetition and recursive pattern of Wounaan stories to soak up, teach, and learn, which also, as CPI has mentioned, is crucial so that meaning is clear. Likewise, in our meetings we are intentionally repetitive to give time for capturing, reflection, consideration, and conversation before moving forward. Much like the description of the First Nations approach to higher education as the four Rs of respect, relevance, responsibility, and reciprocity (Kirkness and Barnhardt 1991), we have written about our respect for each other and for collaborative recursive process, flexibility, and communication as keys to our approach (Velásquez Runk and Opua 2018). We also attend to a cultural norm of reciprocity and redistribution (Velásquez Runk 2014). Our co-work method is Indigenous research, centered in Indigenous value systems and historical contexts and where community members have authority over the research process (Leyva and Speed 2015; Smith 2002). After Wounaan approvals, we obtained human and cultural research approvals in the U.S. and Panama.

We began the first project. We first talked about whether there are any relationships with birds that are not to be made public, that are to be refused; Wounaan team members, after also consulting with elders, said there were none. Then, we sat together conversing (and subsequently messaging) about key bird relationships we wanted to make known and a bit uncomfortably divided a relational whole into digestible categories: Wounaan ethnotaxonomy, art, pets, naveling (chaai $p^{\prime}$ oo $n \Lambda m^{\mathrm{W}}$ ), riddles, dancing, a fact about feathers, dances, omens, and stories. The result came together quickly as a four-page handout illustrated with photos. In both a Spanish and English version, it was somewhat regrettably titled "Some roles of birds in Wounaan culture." It was timed with an Audubon Society 
Christmas Bird Count in January 2018, and distributed during a community event (Equipo Cultural Wounaan 2018a, 2018b). We worked on ethno-taxonomy, repeatedly refusing to make literal translations of scientific names. Later that year, we were invited by Felice Wyndham (with funding from the British Academy) to join a workshop in which Indigenous and non-Indigenous researcher teams from throughout Latin America exchanged experiences about their ethno-ornithology work together. We decided to present on the convivial respect, embodiment, and beauty of birds through Wounaan music and dance. We had already conversed about those relationships and we videoed the Panama City dance group, in which both RIP and DCM participated, so others could hear how the birds were characterized by the flute music and embodied in dance. JVR and DCM traveled together to participate in the exchange at the International Society of Ethnobiology meetings in Brazil (presenting it again with RIP playing the p'ip'an flute at the Conference on the Anthropology and History of Panama in 2019) (Ismare Peña et al. 2018, 2019). The team also worked on the meanings of bird names in Wounaan meu. We then began developing our final publication from that first project for the Wounaan community.
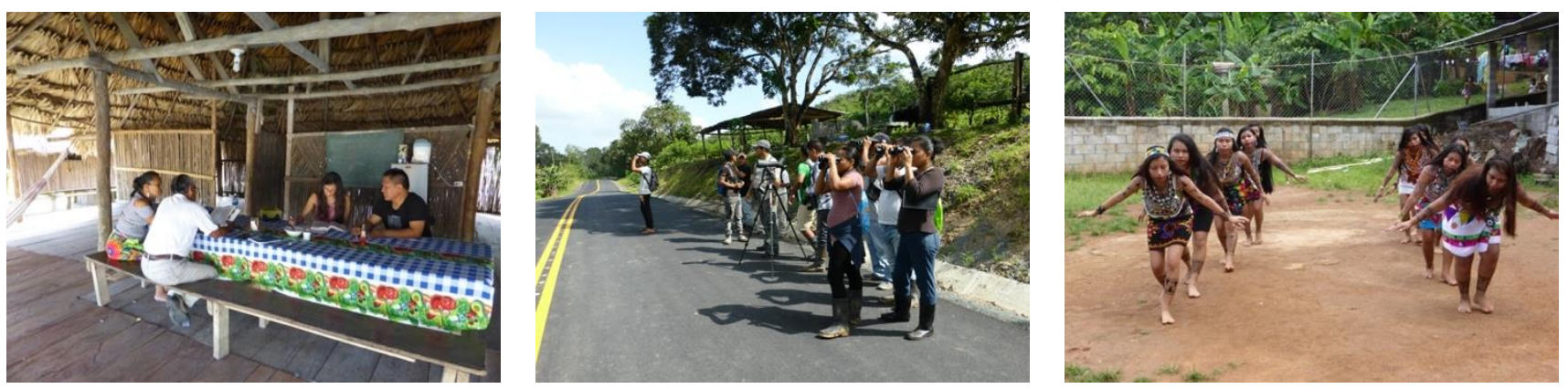

Figure 1. Our collaborative Indigenous method. Left: a work party in Puerto Lara, December 2017. From left to right: Doris Cheucarama Membache, hapk' $\Lambda$ $n$ Rito Ismare Peña, Julia Velásquez Runk, Chenier Carpio Opua. Middle: a monthly bird guiding and identification workshop in Puerto Lara, December 2017. Right: a still photo from a video of the black vulture dance, hãk' ós jemk'aa ${ }^{\mathrm{W}}$, with the Panama City dance group directed by RIP, July 2018.

For that first project, in March 2019, we created a laminated, quadfold educational flyer for schoolchildren in Wounaan meu (Equipo Cultural Wounaan 2019b). It was designed so that children could easily carry it outside, even in the rainy season. We chose birds from those observed in the community, from the Wounaan meu-English-Spanish-Latin scientific name bird list we developed (Equipo Cultural Wounaan 2019a). However, the funder underappreciated it, partly because they could not read it and also because the clean Wounaan aesthetics belied the lengthy process of development and refinement. We were constrained by the budget, and in order to maximize it we were grateful for professional illustrator Dana Gardner's donation of digitized bird illustrations. By using those illustrations of individual bird species, we had reinforced that Linnean taxonomic approach that we had repeatedly struggled against throughout the project. For the community of Puerto Lara, the flyer was very important, and they invited DCM to hold classes on Wounaan meu grammar and writing. It also allowed the second project to teach about birds using the Wounaan meu names, in addition to Spanish and English ones.

With our learnings from that publication, we were more purposeful on the second project publication, to respect the everyday conviviality of life with birds and others. We decided to create a children's book as a rupture, an anticolonial strategy to use a medium that had once been used to normalize colonialism with children (Dorfman 1983). We toyed, however, with what to call it-children's book, picturebook (Daly 2019), or something else-and we settled on illustrated story book, to ground it in Indigenous stories and to be explicit that it was not just for children. As of this writing, we are sending the book for printing and finalizing the audio of the digital book, Wounaan chaain döhigaau nemchaain hoo 
wënı $\mathrm{rrajim/Los} \mathrm{niños} \mathrm{wounaan,} \mathrm{en} \mathrm{su} \mathrm{aventura} \mathrm{vieron} \mathrm{muchas} \mathrm{aves/The} \mathrm{Adventures} \mathrm{of} \mathrm{Wounaan}$ Children and Many Birds.

We approach this article as Indigenous storying, of telling and crafting, through the doing and knowing of co-creating the illustrated story book. The work aligns a framework of Indigenous storywork as respect, responsibility, reverence, reciprocity, holism, interrelatedness, and synergy (Archibald 2008). We recognize some of the copious and rich Native American and First Nations scholarship on lifeworlds and stories and the often difficult-to-access Latin American scholarship on the same (e.g., Archibald Q'um Q'um Xiiem et al. 2008; Corntassel 2009; Justice 2018; Köhler et al. 2010; Kopenawa and Albert 2013; Kovach 2018; Mecha and Escobar 1998; Olalde Ramos 1996; Peña 2009; Rocha Vivas 2013; Simpson 2017; Smith 2002; Uzendowski 2012; Windchief and Pedro 2019). The isthmo-Colombian area (lower Central and northwestern South America) increasingly is known as a distinct cultural region (e.g., Halbmayer 2019, 2020). Wounaan are a people of that region and share a language family with only one other Indigenous group (and its multiple dialects) (Constenla Umaña 1991; Peña 2009); we favor Wounaan ways of description. For example, we use English that is inspired by Wounaan meu and Spanish, for example, "hãba poso honee $n \Lambda m^{\prime \prime} W$ as "convivial," use gerunds to express the fluidity and action that is common in Wounaan meu, "discussed" for U.S. contexts and "talked about"

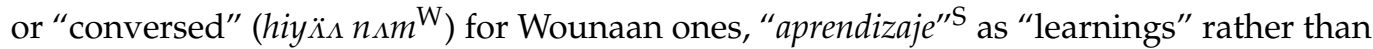
"knowledge".

This organic article style is our storying, and we have intentionally tried to indicate the telling and crafting, the laborious and recursive process of artistic creation, of weaving and polishing. We use "weaving" from the verb $k^{\prime} a^{\mathrm{W}}$ (to weave, tejer ${ }^{\mathrm{S}}$ ) to describe thoughtful creation using multiple materials. Weaving recognizes that, like Wounaan everyday and commercial basketry, thoughtful artistic creation requires the careful bringing together of multiple elements - as strands, colors, technique, and form-in a synthetic whole and, often, in the company of others. This reminds us that $k^{\prime} a^{\mathrm{W}}$ as a noun also means daughter and body, and among Wounaan it is women who typically weave. We have long used "polishing" to describe thoughtful revising. We use the Spanish "pulir"S, as the Wounaan meu verbs depend on the medium, such as peeurpaa ${ }^{\mathrm{W}}$ for a carving and jiirt'e $u^{\mathrm{W}}$ for a canoe $\left(\right.$ jap $^{\mathrm{W}}$, piragua $\left.a^{\mathrm{S}}\right)$, both typically done by men. Polishing recognizes that, like rosewood carving, thoughtful artistic creation is a long process, elongated further by the intentional, careful, and sequential rounds of sanding and polishing. These rounds are often done by others working alongside one another: for carving, they frequently are done by the artist's younger brother or other relatives who still are learning the craft. We also use both verbs to be attentive to gender, as in Wounaan meu the verb "to be" is a gendered honorific, but otherwise words and personal pronouns are not gendered. As egalitarian peoples, individual expertise is not typically exalted and we have tried to comply with Wounaan norms of humility in our writing. We have incorporated all of our voices throughout this narration; however, this has had the result of naming JVR and FG as non-Wounaan who had bridging roles. In this storying, we weave in the fluidity of multiple temporalities, experienced as the cyclical suns and moons, rains and tides, and the transcendence of the ancestors' past in the present. We use references to linear time here to underscore historically non-Indigenous time, and the difficulty of Indigenous methods within the short confines of grant and academic calendars. Importantly, this also is a pandemic story, as we began the book when we could not be physically together and met through video conferencing meetings and messaging. We were further disrupted by the pandemic, suffering tragedy within our team and for Wounaan people.

This story, that is, this article, is based on Wounaan meu, Spanish, and English conversations, video conference recordings, voice and text messages, meeting minutes, notes, recollections, and a recent conference co-presentation. We often send voice messages rather than texts, reflecting the importance of the spoken word, and that not all Wounaan meu characters are on cell phone keypads, allowing messages in Wounaan meu and Spanish, and code-mixing between them. Additionally, as we have done before, JVR wove 
this story on paper in Spanish and English, we shared drafts, conversed and messaged about edits and peer reviewers' comments, and polished the narrative.

\section{Temporalities of the Past in This Storywork}

"In olden times our ancestors were very fit/capable and quick to get things done, not lazy like people today. But the reason they were like that was because mothers' naveled them well" (Peña 2009, p. 64). "There are two birds that are very important for $p^{\prime}$ oo $n_{\Lambda} m^{\mathrm{W}}$ : $k^{\prime} i e r r b \Lambda i$ had $d^{\mathrm{W}}$ [crested guan] and $p^{\prime} e t^{\prime} a u b_{\Lambda}{ }^{\mathrm{W}}$ [rail]." Dorindo Membora Peña, September 2021. "We consider the tradition of $p^{\prime}$ oo $n \Lambda m^{\mathrm{W}}$ to be almost extinct in Panama" (Velásquez Runk et al. 2019a).

Long before the popularity of narrative theory, ecocriticism, and scientific storytelling, we, like many Indigenous peoples, knew the importance of stories (Cajete 2000; Corntassel 2009; Kovach 2009; Peña 1986; Simpson 2017). Wounaan ancestors' stories (jöoingarm nem hig $k^{\prime} a a^{\mathrm{W}}$ ) are the way we know our being, who we are, how to be in the world. The Wounaan corpus of stories is quite large, and in previous work, we archived and repatriated over 400 recordings and DCM and CPI were among those who transcribed 70 of them (Carpio Opua et al. 2015). Stories include the origins of the world and Wounaan, how we obtained maize and fire, and many, many others (Peña 2009). In addition, as is found among other Indigenous peoples, some European and African folktales also have worked their way into the corpus of Wounaan stories (Sherzer 2003; Taggart 1986; Velásquez Runk 2017).

For thousands of years, Wounaan stories were transmitted orally. Nem higk'aaW , to tell stories (echar cuentos ${ }^{\mathrm{S}}$ ), is convivial and communal, with one main storyteller, one who knows how to tell stories (nem hig $k^{\prime} a m i e^{\mathrm{W}}$ ), and listeners interjecting, teasing, and often trying to clarify and even distract (Binder et al. 2013). Storytelling is storying, relational and performative, with the verbal poetics of Wounaan meu accentuated through the onomatopoeia of nouns and verbs, sounds, and accentuated by the elongated vowels and abdominal pulses for emphasis (Binder et al. 2013). Listening to a Wounaan story is entrancing even if you do not understand the language, as experienced storytellers use language, sound, and gestures to story and the gathered participate (Binder et al. 2013). Stories were regularly told, especially nightly in the multigenerational, extended family households when homes were located hours from another, dispersed along the rivers of the landscape of maach duur ${ }^{\mathrm{W}}$ (Binder et al. 2013). In the last thirty years, storytelling has diminished markedly, a victim of settler colonialism, fewer multigenerational households, growth of Christian stories, and non-Wounaan formal and non-formal education, including the expansion of electricity and its television stories. Today, elements of stories are commonly known, but not their details (Velásquez Runk 2020b). Now, one is most likely to hear stories at wakes when we stay awake through the night in to mourn and honor the life of the deceased (Binder et al. 2013).

Non-Wounaan missionaries also recognized the importance of Wounaan stories. Evangelical and Catholic missionaries have long been attentive to stories as ways to translate Christianity (Loewen 1961; Lotero Villa 1972). Most prominently, the Mennonite Brethren, beginning in the 1950s, and the Summer Institute of Linguistics (SIL), beginning in the 1970s, worked on the Wounaan meu language, and recorded and transcribed scores of Wounaan stories. They also were used as source material for translating the Bible, fostering Wounaan writing workshops (including teaching CPI, RIP, and DMP how to write), and evangelizing through language learning and hymnals (e.g., Peña et al. 1987; Peña and Ismare 2007; Peña and Peña 1986; Peña 2006). Some Wounaan stories were made into SILpublished books (e.g., Cheucarama and Chamarra 1977; Ismare 1978). Now, the majority of Wounaan in Panama are Christian, most through the United Evangelical Church (part of the Mennonite Brethren), Catholicism, and other evangelical faiths, maintaining syncretic beliefs (Velásquez Runk 2017).

Anthropologists also have recorded Wounaan stories. These included early recordings, which seem to have been shortened versions told in Spanish to Swedish ethnographers Erland Nordenskiöld and Henri Wassen mostly in Panama (Wassén 1933; Wassén 1963). 
Colombian ethnographer Gerardo Reichel-Dolmatoff also transcribed Wounaan stories, apparently shortened and relayed in Spanish (Reichel-Dolmatoff 1962). Martin Diskin did as well, completing his 1963 thesis on Wounaan "folktales," also evidently relayed in shortened form in Spanish in Colombia (Diskin 1963). Elizabeth Lapovsky Kennedy recorded hundreds of Wounaan stories in Wounaan meu during her doctoral fieldwork from 1964-1966 in Colombia (Lapovsky Kennedy 1972). By the early 2000s, when JVR worked with the WPNP and Foundation, relatively few older people felt comfortable enough with the detailed stories to record them and did so alone (Velásquez Runk 2017).

From 2010-2014, many of us (CCO, DCM, CPI, and JVR) also had worked on a project digitizing, transcribing, translating, archiving, and repatriating to Panama and Colombia 60 years of Wounaan stories (Velásquez Runk and Opua 2018). Our familiarity with many Wounaan stories deepened and we also developed experience in the politics of translation. We know that Wounaan ways of speaking can be difficult to translate, such as verb evidentials, onomatopoetic nouns and verbs, and ideas about culturally important concepts (Binder et al. 2013). As that project ended, we repeatedly co-presented on Wounaan linguistics, socio-linguistics, and our collaborative process (Binder et al. 2013, 2015; Carpio Opua et al. 2013, 2015; Carpio Opua and Velásquez Runk 2013).

Our second bird project grant was approved in July, 2019 for work in the Wounaan communities of Río Hondo and Río Platanares in Panama Province. The month before, all but DMP and FG had presented together on bird relationships through music and dance at the Congreso de Antropología e Historia de Panamá (Conference of the Anthropology and History of Panama) and the Panama City-based Wounaan dance group demonstrated dances (Ismare et al. 2019). Upon finalizing the grant paperwork in late July, our team met through video conferencing, as JVR was then in the U.S. Following our first project, we talked about creating a book about "all" Wounaan-bird relationships about dances, omens, naveling, stories, and bird illustrations. This was a wonderful idea but was not anything that could be accomplished in the rushed span of a year. After all, the creation of a 2-page flyer took many months and much polishing for grammar and spelling (as there is no spell check in Wounaan meu). We knew that such an encyclopedic book would take years to do well. Then, a couple of weeks later in August, Wounaan authorities of the WPNP and Fundación hosted our first planning meeting. We revised the book plans to have two volumes, with the first on the conviviality of relationships of birds, people, and environment (maach hëe $e^{\mathrm{W}}$ ) in Wounaan lands and waters and the second, were we able to finish it, a more encyclopedic work on bird relationships.

Then, we had the first meeting of our cultural team (about a week later). Our initial concern was the limited funds to develop, illustrate, and publish a book, particularly given the cost of illustrations. In the project planning, DCM and RIP, already an elder, were going to interview elders to further develop ideas about Wounaan relationships with birds. From September to December, we broke the monthly work down into one day of interviewing, one day of working on the multilingual bird list, and one day of developing the story. The interviews were dropped because DCM and RIP already knew so much and because doing so allowed them more communal time. CCO committed to speaking to a well-known Wounaan illustrator who was notoriously busy; if he could not join the project, he would seek another illustrator. From January forward, we would focus entirely on editing the book and illustrations and getting it to press. As we will return to later, the need to earn income, the many responsibilities of authorities, payment delays, and the pandemic made our scheduling impossible to keep. We moved into a more organic model of conversing in fits and spurts as the team was available, healthy, and connected to the internet.

In that first team meeting, we conversed together about ideas for the book. We reviewed the decision to make an illustrated book about Wounaan relationships with birds, and established that it would be written in Wounaan meu, with Spanish and English secondary to it. The goal was to finish the narrative in January and then work on the book's illustrations and formatting until the grant's July termination. CCO, DCM, and RIP had already met the month before and decided to highlight bird relationships of dances, 
omens, naveling, and stories, with bird illustrations; similar to the first grant, they also had considered particular birds (species) to highlight based on the ones they had recorded in the communities (Table 1). However, we talked about how this reduced Wounaan relationships into categories, rather than the holistic, interconnected lifeworlds that people live. We also talked about making sure that we were not repeating the only model we had on hand, a Guna book on birds that included academic discussions on ontology, bird lists, and illustrations (Martínez Mauri et al. 2014). To address these differences, JVR messaged photos from that book and encouraged everyone to think about what they wanted for Wounaan, because the book did not have to be like the Guna example. CCO, RIP, and DCM were going to consider options and create a workplan. In their work in rural communities, they also were going to take photos of birds in Wounaan weavings and carvings and in everyday life. In September, seeking to get some creative advice from Indigenous community and researcher teams, we developed a poster about the laminated quadfold for schoolchildren for the Intersections of Language and Nature conference. The poster ended by asking conference participants for their advice and suggestions for creative works on ethnoecology and lifeworlds for children, including sticky notes to do so (Velásquez Runk et al. 2019b). There were no suggestions for projects that focused on children. In October, JVR messaged a link to an almost 400-page book from Mexico titled Aves, Personas y Culturas (Birds, People, and Culture) (Vásquez-Dávila 2014).

Table 1. Birds selected for the story.

\begin{tabular}{|c|c|c|c|}
\hline Wounaan meu & Spanish & English & Scientific Name \\
\hline b̃̃skiu & garza dorsiverde & green heron & Butorides virescens \\
\hline$p^{\prime} e^{\prime} a u$ & $\begin{array}{l}\text { rascón-montés } \\
\text { cuellirufo }\end{array}$ & $\begin{array}{l}\text { gray-cowled } \\
\text { wood-rail }\end{array}$ & Aramides cajaneus \\
\hline pëp'amie & trica, cuco ardilla & squirrel cuckoo & Piaya cayana \\
\hline k'urp'im & loro cabeciazul & blue-headed parrot & Pionus menstruus \\
\hline kokolot & $\begin{array}{c}\text { garceta, ibis, cigüeña, } \\
\text { y heron (chose } \\
\text { garceta nivea) }\end{array}$ & $\begin{array}{c}\text { egret, ibis, stork, and } \\
\text { heron (chose snowy } \\
\text { egret) }\end{array}$ & chose Egretta thula \\
\hline hãk'õs & buitre (chose gallote) & $\begin{array}{c}\text { vulture (chose black } \\
\text { vulture) }\end{array}$ & chose Coragyps atratus \\
\hline döt'egmie & $\begin{array}{l}\text { martin pescador } \\
\text { grande }\end{array}$ & ringed kingfisher & Megaceryle torquata \\
\hline kekerr & $\begin{array}{c}\text { periquito } \\
\text { barbinaranja pasifico }\end{array}$ & $\begin{array}{c}\text { orange-chinned } \\
\text { parakeet }\end{array}$ & Brotogeris jugularis \\
\hline bisierrín & tucancillo collarejo & collared aracari & Pteroglossus torquatus \\
\hline pies & $\begin{array}{l}\text { colibri (chose } \\
\text { amazilla colirrufa) }\end{array}$ & $\begin{array}{l}\text { hummingbird, (chose } \\
\text { rufous-tailed } \\
\text { hummingbird) }\end{array}$ & chose Amazilia tzacatl \\
\hline
\end{tabular}

In both Panama and the U.S., we looked for an illustrator. Panama's foremost Wounaan illustrator, Chafil Cheucarama, had illustrated most of the SIL books with pen and ink drawings (e.g., Binder et al. 1978; Peña Ismare 1997, 2007; Peña 1989), but he was employed by Panama's National Cultural Institute and could not complete the illustrations in the tight timeframe. The preference was for a Wounaan illustrator, but there were serious doubts as to whether one would be located to develop the illustrations so quickly given the restricted funding; hence the decision to seek an illustrator in both countries. We decided that the WPNP would hold a contest to select an illustrator: Wounaan and other illustrators were to complete one scene by the deadline and the WPNP would select from them. At her university, in October, JVR had a meeting with art professor Michael Marshall on another topic. She mentioned this book project and he suggested it as a great final project for an 
undergraduate in the scientific illustration program, which JVR did not know existed. He asked her to write a paragraph about the project for the lead of that program, Gene Wright. Then, Gene followed up by asking about illustration style to be able to suggest a student. We had not yet decided on the form nor illustration style of the book, so JVR sent copies of the Guna book with its paintings by Spanish artist Cristina Zafra (Martínez Mauri et al. 2014). She described that Wounaan have a clean and artistic aesthetic with a preference for bright colors. She also made clear that the project was a collaboration, that Wounaan had ultimate decision making on representing and revering their content. The illustrations would be developed collaboratively, using photos and videos as guides, and, possibly, a trip to Panama.

Given our objectives, we decided on creating an illustrated story book. In one video conference, JVR suggested a children's book, or as she translated it, an illustrated story for children. The medium was unknown to Wounaan team members. Known in Spanish as libros infantiles $\mathrm{S}$, infants' books, we have elected not to use that term because we find it, well, infantilizing (likewise we have decided not to use the term picturebook because we wanted to ground this work in Indigenous stories). The many SIL published books were illustrated, but the black and white line drawings were geared to Wounaan adults who already spoke Wounaan meu and were learning to read the language. Wounaan children in the city watch weekend cartoons on TV, and we considered a book as a mix of story with cartoons or colorful illustrations. MK, also participating, suggested that an illustrated story book might be a good option because the combination of images and written narrative were geared towards children, who were our intended audience for cultural revitalization and resurgence.

An illustrated story book had a few advantages. Most importantly, it could be based on the narrative form of ancestral stories. As mentioned earlier, we knew Wounaan stories and also the decline of nightly storytelling. We wanted to value stories, of knowing and doing and being through this Indigenous medium and craft a new story that reflected back to the ancestor's ones: a story made by Wounaan in Wounaan meu for future generations. As such, the story was a rupture, using Indigenous storywork as an anticolonial method to craft a political intervention that was the requisite book. In addition, we could ensure that both the narrative and images honored Wounaan lifeworlds, while also using multiple languages and beautiful images to make it available (and sellable) to others, particularly the birdwatchers who were enthusiastic about the project. The narration/naración $n^{\mathrm{S}}$ also could be relatively short, allowing us to easily correct and polish the Wounaan meu and translate it into Spanish and English within the one-year grant time period. We liked the illustrated story book idea and then focused on developing the story and recruiting an illustrator.

We video conferenced again in January 2020, by which time we had messaged about and decided to create an illustrated story book. During the prior months, we had continued to message each other as CCO, DCM, and RIP supported the bird list work in the rural community of Río Hondo. In our January meeting, we listed the main objectives for our publication, with stories as something of a taken-for-granted epistemology:

- $\quad$ Teach Wounaan children about birds in culture;

- Teach Wounaan children about bird names, customs, and habitats around them/in the environment [maach hëe $e^{\mathrm{W}}$, entorno $\mathrm{S}$;

- Support the Wounaan culture in all its complexity;

- $\quad$ Respect the culture in rural communities while recognizing that many Wounaan now live in cities;

- Demonstrate to children how to write their language;

- A two-volume set. As we described it in our meeting notes: 
The first volume will be a small illustrated story of two siblings walking/moving/ socializing in their community, experiencing different situations with birds and beliefs about them in everyday life. This volume focuses more on illustrations with a little text.

- The second volume will be more information with respect to birds in culture. There, other examples of omens, naveling, dance, and stories with birds can be detailed. In addition, in this volume it is important to indicate that birds are only a part of the animal and plant beings in the environment (maach hëe ${ }^{\mathrm{W}}$, entorno ${ }^{\mathrm{S}}$ ).

We really wanted to do the two-volume set, and repeatedly came back to it over the next ten months, but eventually decided that to do the illustrated story book well, we had to discard the second volume, for now.

We also decided to make a multimodal publication, making it available digitally and in print. Due to Panama's free trade zone, smart phones are relatively cheap and fairly common among Wounaan. The publication could be both a free digital book for Wounaan children and a print-on-demand book with the earnings going to the Wounaan Podpa N $\mathbf{m}$ Pömaam. A digital book could revere Indigenous storying, allowing us to include audio of Wounaan meu narration, music, and bird calls.

\section{Weaving Wounaan Lifeworlds in Illustrated Story}

"Now comes great pressure, because ... it is like a fashion that ancestral stories, ancestral knowledge, botanical knowledge, it is like a boom now ... [something that] everyone wants to work on ... but without even having [knowing/experiencing] how [Indigenous people] live and how they eat. So, all that [doing it well], everything will depend on the authorities in each case, like the Congress. Thanks to the opportunity [of the Wounaan Oral Traditions Project], we have everything [all the stories] saved." Chenier Carpio Opua, September 2021.

Beginning in January, 2020, we repeatedly video conferenced and messaged to develop a story. During the first video conference of 2020, we were joined by Foundation President Novel Carpio Mepaquito (NCM), national chief Diogracio Puchicama Peña, and MK. JVR and MK sent links for children's books for everyone to look at during the meeting and we considered the prominent illustrations and the relatively short narrative. We all had a better idea about the format and began working on the story. The easiest decision we made was about the protagonists. As we wanted children to be the main audience, we decided that the protagonists would be children. We also knew that it could not be a sole protagonist, as that would not best represent kinship and community in Wounaan lifeworlds. We opted for a brother and sister, intentionally allowing for gender parity in egalitarian Wounaan life. To figure out the story arc, we took inspiration from the story known as Chaain numi $b^{\prime} \wedge p^{\prime}$ urrsir hee t'aabatarr $k^{\prime} \Lambda \Lambda n^{\mathrm{W}} /$ Los gemelos nacidos de la pantorillaS / The Calf-borne Twins, in which twin brothers travel to many places in attempting to avenge their parents deaths (Peña 1986). Wounaan often refer to the story as the twins' adventures. To honor Wounaan lifeworlds in rural communities, rather than the pull of the cities, we talked about making the story an everyday adventure of siblings as they experience birds throughout their day, a story that would draw forth the sociality and conviviality of life. We had bird relationships we wanted to highlight, sibling protagonists, a narrative arc of everyday adventure, and now we just had to develop the story. Book writing was new to most of us. As DCM said, "In reality ... to make this book was a bit hard; better said, it was hard. If it were me alone, I would not have an idea about how to start, how to begin, how to create it; it was difficult ... This is almost a poem." 
To create the story of a brother and sister's adventures, we would weave together the selected bird relationships, with bird dances, omens, naveling, and stories. To begin, we considered a book of ten scenes, an amount that let us build a story around those bird relationships and one based on the Wounaan counting system of hands: 10 was two hands $\left(\right.$ jua $\left.n u m i i^{\mathrm{W}}\right)$. We then talked about how to weave them into a story, a story of a day of adventure. The day was that temporal cycle of suns and moons, but one in which we wanted to underscore the past in the present and the future: we decided to make the story in the present, the present of a rural community (Peña 2009). We also considered if any other important relationships were missing and added birds as beings of lands and waters that are cared for and sustained, pests of crops, and pets. DMP said "the book has to tell stories to children that in is writing says that we should ... care for [animals]," a sentiment that was repeated by CPI.

We sequenced the bird relationships throughout the day as scenes and talked about creating a story that would weave them together. In an early video conference, one of the gathered Wounaan asked JVR to develop the story and she refused, saying that she knows about Wounaan, but is not Wounaan: it was important that this story be about Wounaan by Wounaan. Authority NCM backed her up, encouraging RIP, DCM, and CCO to develop the story. Together in that video conference, we began to outline the story, talking about key ideas to relay. JVR prompted with questions like "How shall we start the day? With bathing in the river? Sleeping? Something else?" We wanted to emphasize the autonomy, conviviality, responsibility, and movement of Wounaan life, making sure that the story moved among the community, river, and lands that are key to life. This also would allow us to show birds in diverse habitats. In that meeting, we worked together to outline the initial narrative and key scenes. We had a list of important bird species for each relationship and would select from them when writing the story, taking care to show birds in diverse environments. The story moved quickly from the home to the river, back to the community, to upriver maize fields, back downriver to the community, to bathing at the river, back to the community for a family meal, and to the home with both storytelling and dreaming. Ending the day with storytelling was done to focus on its importance, of the past in the present, and connecting this book with it. Dreaming is a crucial means of learning new knowledge (and not just oneiric, onírico ${ }^{\mathrm{S}}$, as is frequently described), including how one learns words for the haahi jëeu $n \wedge m^{\mathrm{W}}$ ceremony with the $k^{\prime} u g w i u$ prayer/petition canoe for communication with the Creator, Hẽwandam ${ }^{\mathrm{W}}$ (Peña Ismare et al. 2020). We made sure that a bird was in every scene, even if it was not explicitly named in the narrative. We confirmed which bird species to use, adding the species names to the idea we had for illustrating each scene (Figure 2).

Then, CCO, DCM, and RIP were to meet together and develop the story. Before they did, we decided to reduce the eleven scenes above to ten, to jua numi ${ }^{\mathrm{W}}$. We also talked about honoring the spoken word of Wounaan storying, rather than the written word. We conferred about storytelling, about the verbal poetics of it, which DCM and CPI had conscientiously been attentive to when transcribing and translating stories in the stories project a few years before. We suggested that once there was a consensual story among RIP, DCM, and CCO, that the story be spoken in Wounaan meu into a digital recorder by RIP, an extroverted storyteller. DCM and RIP could then transcribe the recording. The story was to be completed within two weeks and then CPI would correct the orthography and grammar. 


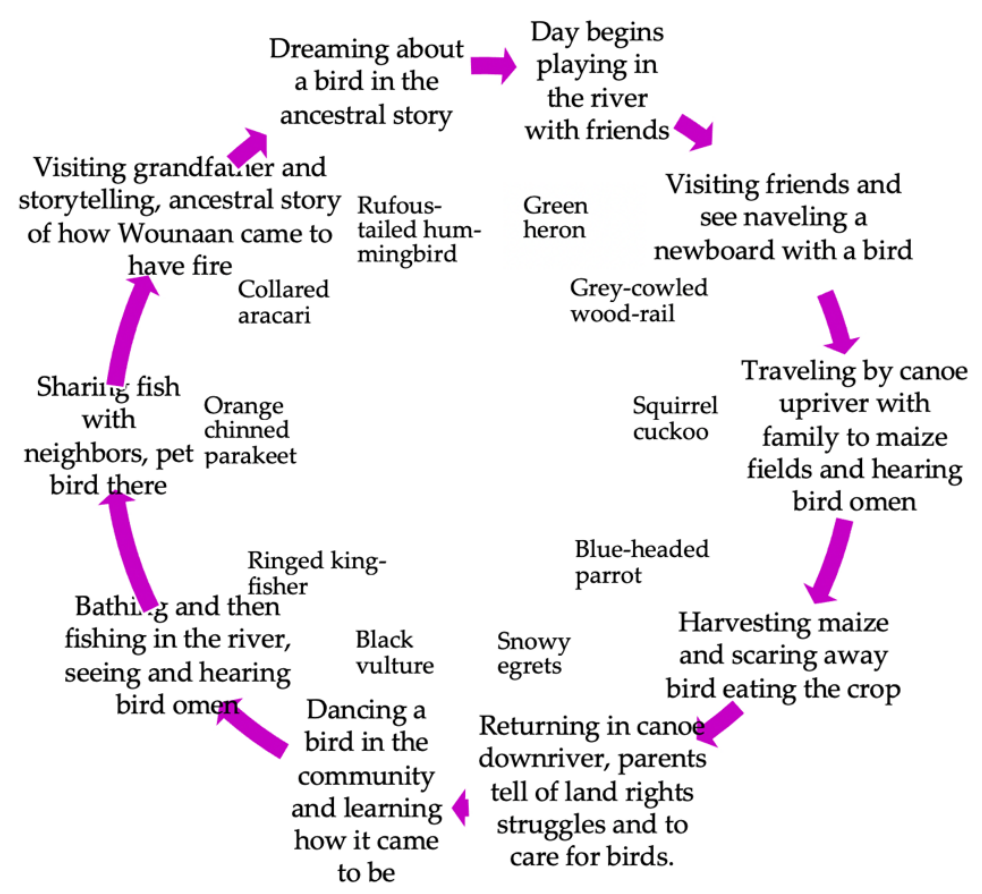

Figure 2. The sequence of the story and its birds. The story cycle was that of the day, weaving convivial knowing and doing through the movement among community, rivers, and lands. We gave attention to caring for community, land, and others, including birds.

With a book outlined, CCO and JVR again worked on finding an illustrator. CCO called and messaged Wounaan who drew or worked on design. They had decided to set the illustration contest for the end of the month, asking each candidate to make an illustration of the scene of the children bathing in the river when a kingfisher flies by with its message. JVR had traveled to a conference in Guatemala, returning with three children's books in Spanish, including two Indigenous ones, and she sent DCM, RIP, and CCO photos from each to begin to think about style (Mathis Pitts et al. 2019; Ojeda and Palomino 2011; Serrano Echeverría and Che-Novak 2018). JVR got back in touch with the scientific illustration program's Gene Wright. He had selected a possible student, Frankie Grin. When JVR and FG first met, FG showed a remarkably diverse portfolio of painting, drawing, and digital work. In addition, she was from southeastern Florida and in one portrait she had painted a background of tropical vegetation. They discussed the team's decisions for the book, including the audience and storyline. They also talked about the illustrator contest and the requisite first work. FG kept asking about style, but JVR was not familiar with many of her artistic terms, so they looked at style via many children's books. To familiarize FG with Wounaan aesthetics, they looked at Wounaan carvings of tagua and cocobolo, with FG impressed with the movement of the pieces; figurative hosigdi ${ }^{\mathrm{W}}$ (coiled) basketry was later added to these (Figure 3). JVR talked about Wounaan life, conviviality, and the importance of water, pulling up digital photos and videos to illustrate. She also gave FG a DVD copy of The Wounaan Trilogy, three films made by Liz Lapovsky Kennedy (LLK) during her 1964-1966 dissertation work in Colombia (Kennedy and Kennedy 2011). The stories project (which included CPI, DCM, and JVR) had reviewed and corrected the voice over in 2011, and joined LLK, and Panama's national Wounaan authorities (RIP and (CO) to rep/matriate and distribute the digitized films to Wounaan in Panama and Colombia in 2016. JVR set up a shared drive with photos and videos that FG could use to aid in the illustration, with FG promising to destroy the copies after the work was done. 

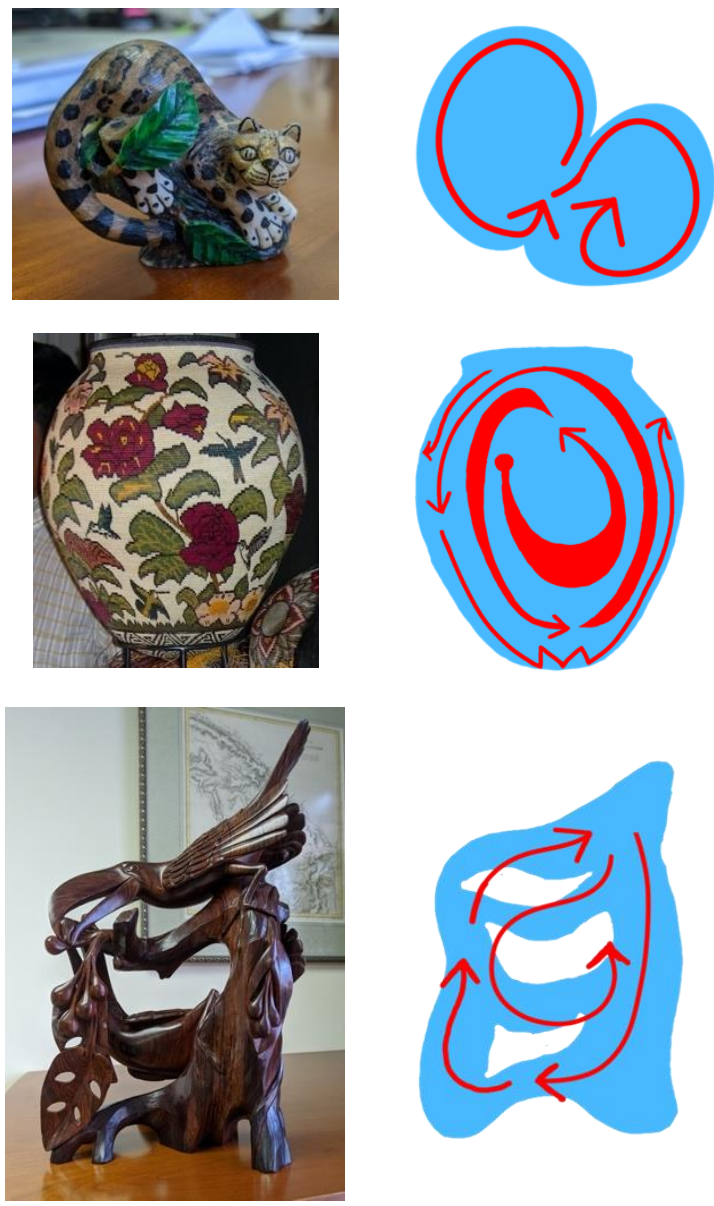

Figure 3. Movement in Wounaan art as inspiration for movement in the story book illustrations. (Top): In the tagua carving by Eloy Membora, the ocelot's face and the large leaf are the focal points, showing how shape/form is used to achieve harmony or coherence. (Center): In the chunga basket by Loida Mejía Ortíz the red flowers contrast against the green leaves creating a focal point. The wings and beaks of the hummingbirds plus the stems of the plants guide the eye in a circular motion, which continues infinitely around the volume of the basket. (Bottom): In the cocobolo carving by Alido Membache Donisabe, the use of space and rhythm emphasizes the toucan as the focal point, showing how positive and negative space reinforces rhythm.

JVR and MK also held a meeting with UGA's Digital Humanities Lab within the week. The lab's coordinator, Emily McGinn, suggested two platforms for making the books, one for the digital illustrated story book and another for the more textual second volume. They addressed how the books could be finalized pretty quickly on those platforms. Emily and the DigiLab research assistant Guthrie Armstrong set up the team's accounts on the platforms and tested the successful use of Wounaan meu characters in each.

At the end of the month, FG won the illustration contest. In her original painting, she was able to skillfully illustrate birds, people, and water, a tough combination. She brought to the collaboration design language, as she later wrote, "just as we must translate from Wounaan meu to Spanish or English, we must translate main ideas into pictural solutions." She also was willing to work within the tight timeframe and receive no compensation as part of her capstone course. JVR had a free plane ticket and told the team that she and FG would come to Panama in May to work with them to finalize the paintings during a stay in a rural Wounaan community. JVR also committed to funding any work that would be required after FG's May graduation. Early on, FG asked to collaborate with a Wounaan illustrator, but CCO determined that no one would be able to do so because the main Wounaan illustrator (Chafil Cheucarama) was unavailable and they had not found 
someone available within the timeframe. We agreed to cultivate Wounaan artists for our next project. Until then, FG drew inspiration from Chafil's ink drawings, most notably through realistic representation of human figures. She "parallels some of his figure-drawing style through the strong, balanced postures of characters both at ease and in mid-action poses." FG was concerned with how many people were in the photos she was provided, because, as she said, it is so time consuming to draw people. In addition, having many people in a scene would make the image composition more difficult, not only because it is harder to draw in the reader's eye, but also, as FG clarified "because negative space is equally as significant and powerful as positive space." We took these issues into account, making the sociality move through the story rather than in any one scene.

By mid-February, RIP, DCM, and CCO finished the first full version of the Wounaan meu and Spanish narrative. That first full draft was very didactic, more of a telling others about Wounaan life rather than a story about it. It began with "Our custom in the field is this way." JVR, who received the draft, was surprised by this normalization of an outsider gaze, one in which centuries of Wounaan life were "the field." Wounaan authorities had begun to use the phrase after increasing relationships with government officials and the U.S. bird consultants on this project. She spoke with the team about making this more like a story, a story about the children's adventure. In their video conference, they tried out different ways of storying the scenes. RIP talked about new details in the dinner scene: after bathing in the river before dinner, the children also had fished, bringing a favored freshwater fish $\left(\right.$ baaur $^{\mathrm{W}}$, róbalo $\left.{ }^{\mathrm{S}}\right)$ to their neighbors. That fish is featured in stories and its gifting to the neighbors emphasized food sharing and the Wounaan value of gifting/redistributing when one has more than they need. Sharing food also is hö hajaug ${ }^{\mathrm{W}}$, as CPI clarified, being kind in relationships with others, with no expectation of anything in return.

\section{The COVID-19 Pandemic While Polishing the Illustrated Story}

"The dance is an imitation of a bird, and by imitating those birds, [the dancers] feel the importance of imitating that bird, feels joy because when one sees those birds, they are flying as emotion ... So, with joy [the dancers] imitate them, with respect to the way they move in flight. So, by listening to the music, that is how the animation enters [you], that importance, that desire is felt. Then, they [the dancers] imitate that and as part of culture that our ancestors have come practicing." Doris Cheucarama Membache, September 2021.

Our plans for working together in person in March, May, and June were abruptly altered because of the pandemic. JVR was to visit during spring break in March, for which we had planned to work together in Panama City and in Río Hondo. With multiple COVID-19 cases registered in Atlanta airport by 4 March, JVR canceled travel to Panama that day: she feared, however unlikely, unintentionally bringing the virus to Panama and colleagues. That same day, CCO, RIP, and DCM sent out the next narrative draft. This draft was more descriptive, but still didactic. It began "Our ancestors lived on the banks of river and as it was their custom to live in traditional thatched roundhouses, the parents accustomed to waking up early." We again talked about how to make the story about the children's adventure, to tell the story of their day of adventure. RIP, DCM, and CCO would rewrite the story as an adventure and also decide on what should be in each accompanying illustration. They conferred with CPI, who had worked on numerous books and Wounaan stories, about how to do so. Panama reported its first COVID-19 case on 9 March.

In Panama, RIP, DCM, and CCO sent the third draft of the bilingual narrative on 10 March, just before their last team trip to Río Hondo. This draft was the first version that told the story of the siblings' adventure. It began: "One day, a girl named Chibau and her brother named K'õsi, went in a small canoe upriver to bathe. They arrived at a house of a neighbor, where there was a large thatched roundhouse." We talked about this story, now written as a story. As CCO later said "I learned a lot on this project; truthfully, I learned that you also have to write taking into account how writing will be received." The day after the meeting, the World Health Organization declared the COVID-19 pandemic (WHO 2021). The fourth version of the narrative was sent on 12 March. At the point, we 
addressed how the pandemic would curtail the in-person work for some time, meaning we would continue to work by video conferencing, voice and text messaging, and email. That same day, Panama closed schools and workplaces (Woskie and Wenham 2021).

Wounaan authorities and team members worked to respect and support their communities, as by late March the Panamanian government began a series of policies to restrict movement and prevent the spread of COVID-19. By 25 March, the country was under quarantine and then beginning 30 March there were movement restriction policies that lasted until 2021. These were a series of lockdowns in which people were allowed essential activities only during certain hours of the week based on the last digit of their cedula identity card and gender, and then gradual reopenings punctuated by lockdowns (Woskie and Wenham 2021). By late March, some of the Panama and U.S. team members joined with NGOs (including Native Future), indigenous authorities, intergovernmental organizations, scholars, government, and activists in what eventually would be named the Colectivo de Aliados Indigenas (Collective of Indigenous Allies). The Collective coordinated on the pandemic response, including public health messaging, advocating for the government's plan solidario $\mathrm{S}$ distribution of groceries with Indigenous authorities and through few hands, and the creation of a map with demarcated Indigenous areas to visualize the spread of COVID-19 to those areas using the government data (Moutinho 2021; Ventocilla 2020). The WPNP, FUNDEPW, MK, JVR, and CCO created a Wounaan phone tree, a network of people to send messages to cover urban and rural Wounaan. Many of the key nodes were Wounaan who had regular internet access, and for those that did not, they began refilling their cell phones from a distance, which was crucial because stores were not being supplied as frequently under lockdown and people could not buy cards to purchase minutes of cell phone use. Additionally, many urban Wounaan were among the marginalized people who were first laid off by businesses in pandemic job cuts.

FG finished the storyboard on April 3 and JVR circulated it by cell phone and email with the story for comment. The team returned the comments to FG, but both in Panama and the U.S. we began to experience pandemic delays. JVR donated funds to NF to contract for FG's completion of the illustrations after her graduation. We canceled plans to work together in Panama in May and June and worked through regular messaging, especially voice and text messages. The project received its first grant extension to December 2020.

This was an incredibly difficult time in Panama and our voice, text, and email messages on this project were punctuated by pandemic work. Our team includes CCO as an Indigenous authority and RIP as a previous national chief and pastor, both of whom were actively supporting their people and attentive to their needs. Without regular pay, they attended to community requests, continued work on land legalizations, helped distribute government relief, and RIP also distributed video devotions by cell phone to the Wounaan Christian community. DCM was attending University of Panama classes online and supporting the community. JVR provided graduate students' suggestions for remote research during the pandemic, co-hosted a daily graduate student writing group, collaborated with the Collective, and worked on other projects. FG was finishing her academic year and moving to be with her family. Most of us worked on a reforestation guide to highlight Wounaan planting techniques and infographics to prevent the spread of COVID-19 when movement restrictions were lifted, as many of Panama's urban Indigenous people were moving back to rural communities for food security during the pandemic (Osorio Chiripua et al. 2020; Velásquez Runk et al. 2020). Beginning in June, we provided FG with comments on the near final black and white outlines of the illustrations, such as whether the upriver side of an illustration was obvious, that the dancers needed to be more crouched, that hair needed to be silkier, and others (Figure 4). FG said that she had more trouble illustrating men, that in four years of an art program they had had numerous female models, but only one male one. We continued in communication with family and friends and trying to prevent pandemic calamity. Many Wounaan got COVID, often without a formal diagnosis. In early June, CCO lost his elderly grandfather, a well-known flautist and ceremonial practitioner who got COVID in the hospital after another health concern. CCO as both a 
family member and Indigenous authority navigated the complicated health requirements of a burial, including a request to JVR for a eulogy and photos for the family. RIP voice messaged "yes, now our brother Uribe Carpio has left, the great flautist of Capetí. Now there are no longer flautists, only Auciano Barrigon remains. We are grieving with CCO." This was spoken in a somber tone of grief and also with tremendous humility, as RIP was now the most well-known practicing Wounaan flautist in Panama. It was also, sadly, prophetic.

We continued messaging, beginning the rounds of polishing initial color illustrations. RIP gave thoughtful encouragement, praising elements of the paintings, such as the bird forms or colors. FG had painted to show which direction the river was flowing, a change from the black and white outline that elicited RIP's description of "the river is excellent schmexcellent [excelentismo tiofilo ${ }^{\mathrm{S}}$ ], the water is as clear as the water of [Wounaan community] Capetí." This was a common joking way that Wounaan refer to the clarity of a point, by comparing it to a river with clear water, such as Capetí, or opaque water. In a first illustration, RIP and CCO both messaged that the mustache had to be removed from the boy's face, that he was too young for that. FG later recalled that from these comments she realized that she would need to eliminate some of that shading, which furthered her use of a cel-shaded style with simplified colors rather than the gradients that you would see in real life. Many times, RIP, DCM, and CCO's comments were difficult to operationalize, particularly the recurring observation that a person "does not look Wounaan" or, even jokingly by RIP, "that girl cannot be bathing with that boy" to address that K'ósi did not look Wounaan. Initially, comments were often about hair, that hair had to look straighter or silkier, later it was more about the appearance of faces. We worked together to clarify these, JVR prompting with questions such as "what about the man makes him not look Wounaan" or "what about his hair makes him not look Wounaan" or "describe what parts of the face to change and how." FG was gracious about making changes, working off voice messages, many photos, and conversations with JVR. At times, team members would contradict each other as to what had to be done. In those cases, JVR would call and message through a group chat, to determine which advice to give FG.

It was in July that RIP fell ill. He had had two negative COVID-19 tests and felt well before falling ill again. He was gravely ill by the time he got to a hospital. His family was traumatized, never allowed to see him for the five days he was there. Doctors rarely spoke to the family members, who were taking turns waiting to hear from them at the hospital. "He went ahead of us" CCO later said. We supported the family, wrote eulogies, and compiled photos, video, and audio recordings of their beloved friend, colleague, and previous national chief. Due to the negative COVID tests, a number of other Wounaan, including young people, became ill after informal wakes honoring the deceased. There were family members who were too ill to be among the few now legally allowed to go to the burial. We were crushed and grieving. We allowed ourselves time to mourn and to celebrate him.

We slowly began to continue work on the illustrations and narrative together after a couple of very difficult months of the pandemic in Panama and the U.S. DMP joined us as a new member on the team. Without the planned travel to Panama, this was a much more challenging artistic project. From May until September, we continued to provide comments on drafts, as well as photos and illustrations to polish them. As FG developed full paintings, the many reviews were done via cell phone messaging, an easy means to share draft illustrations and voice and text comments about them. Recognizing that in ancestral times, human beings became animals, including birds, FG used this to drive the design style, as she later stated "the human characters and animal characters are represented in the same digital style. This harmonizes their co-existence, while also allowing the artist some flexibility with changes and revisions." She also had intentionally used watercolor in the backgrounds as a central theme to show the importance of the river to Wounaan life. With watercolor, FG has noted, "there is some loss of control because the behavior of water is fairly unpredictable. Allowing the water to move the paint removes 
some control from the artist and thus, the artist's inherent biases which may influence the style, or design language, of the illustration."

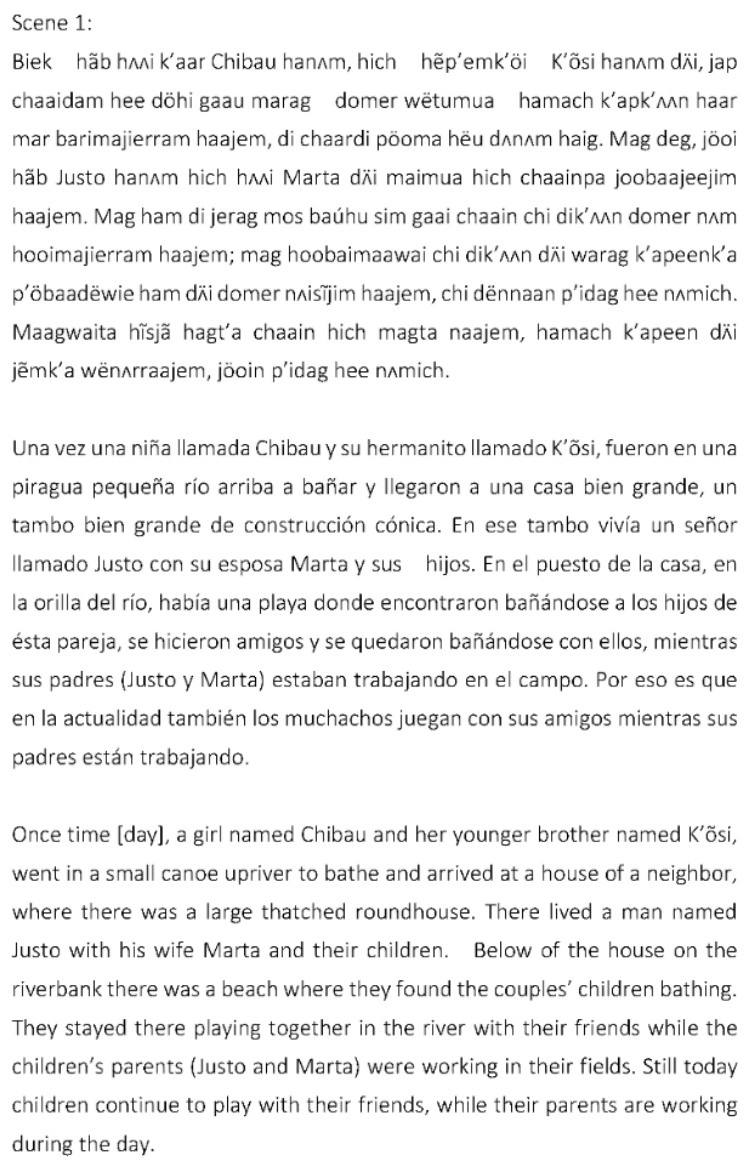

Figure 4. The book's first scene in late April 2020. An early version of the narrative with the initial storyboarded illustration.

From September through November, we had three video conferencing meetings to polish the near final illustrations so that they visually respected Wounaan lifeworlds. On 5 September, we held our first video conference with artist FG and her mother, Liz Green, who graciously translated for her. In this meeting we had intended to review all the images and the cover, but over three hours we only got through seven illustrations. There were a number of changes, and FG did admirable work sorting through them all: which type of mosquito net to illustrate, how to best show the smoking of a bird's foot over the hearth for naveling, whether the birds' sizes and coloring looked about right, how the people's posture needed to be more upright, how skin color could be variable and also, as FG had done, slightly lighter in scenes with more sunlight. JVR showed Wounaan silver jewelry and DCM danced to show the body position for the vulture dance. DCM also selected which designs to use on Chibau and her mother's hapk'ajüaW (parumas, sarong). The most critical edit was to the canoes, a crucial part of Wounaan life that required multiple revisions to get the right shape of the preferred riverine dugout (jap chaar $\mathrm{W}$, the true canoe). When we reviewed the ninth scene which included the story about how Wounaan obtained fire, we conversed about how to relay that the grandfather was telling the story in a way that showed a scene from it. We decided to have it as something like an image bubble. Then, JVR asked how to depict uncle caiman (jöoi $k^{\prime} a i m a n{ }^{\mathrm{W}}$ ) and the hearth, and whether they should be on the ground, in a house, or otherwise. As CPI said, "remember that in your culture the animals turned into people and for us, people turned into animals," from which we talked about how to relay that ideal pictorially. In the end, the caiman was given 
a human-like face with a prominent nose and human skin color, a gourd-cut hairstyle, and a caiman body and he and his hearth were on the ground near a river. We also changed the plans for the cover, which originally was to be a scene from the story of the how Wounaan obtained fire. Although we would have liked FG to make an entirely new cover painting, because of pandemic delays, FG had to be compensated for her additional time and labor, and there were no additional monies forthcoming. Instead, CCO, DCM, and DMP met and made a new composite image based on other images from the story, with the children releasing a young toucan. After that meeting, the team decided to make a new illustration for which JVR paid FG: a frontispiece dedication of RIP playing the flute with his son playing the drum. We provided FG photos of our beloved, deceased colleague to make the painting.

We held our second round of polishing by video conference on 18 October. Among the changes in this set of images were the backgrounds, particularly as the day transitioned into night. FG had made beautiful watercolor backgrounds of an orange that deepened into greens and blues as the evening became night. We talked about emplacement, how because Panama is in the tropics and a few degrees north of the equator, that there are not the long, lingering sunrises and sunsets of the temperate zone: we decided that the backgrounds would just get grayer. We addressed how the parakeet needed to be smaller, the grandfather's loincloth bright red with a thinner string around the waist, and that the mosquito net had to be hung more taut. We noted that the image of the $\operatorname{dichaard} \mathrm{W}$, the raised roundhouse, looked enclosed. Sited adjacent to rivers, the raised pile dwellings are architecture well adapted to the heat and the uncommon, but possible, floods by allowing air flow beneath. We also brainstormed how to best indicate dreaming, opting for something like a scene floating about the mosquito net. Another challenging edit to the illustrations was the house interiors in which a rounded roofline contrasted with squared floors. None of us had a good photo from the interior of the house, so we sent FG line drawings by Chafil and suggested she review Liz's videos. There were so many corrections that we made a new document with the images, the story, and the team's suggestions for polishing the images (Figure 5). This was a crucial decision, allowing FG to better see the suggestions and the rest of us to better see where the narrative and images did not align.

With the near final trilingual narrative and illustrations on hand, we were able to review both together. Between November 2020 and October 2021, we edited the story nine additional times. Those next polishing rounds focused on making sure that the narrative aligned with the illustrations. For example, in the vulture dance scene, the narrative had dancing in a cultural house, but the painting had dancing on the ground, so we edited the narrative so that dancing was in the patio of the cultural house. In that same scene, originally a vulture was sitting in a tree in the background. We edited the story to make clear that the vultures circling high in the sky on air currents is why Wounaan dance that dance, inspired by the beauty of their convivial play. FG then added two flying vultures circling in the sky. Another important edit was to include a direct reference to Wounaan sovereignty and land rights, the struggle for which has been central to Wounaan communities for centuries and the focus of political action for decades. As RIP wrote in 2013 when he was national chief, "we are tired of false promises, while so many Indigenous people little by little lose the most valuable heritage of their existence, the land (Ismare Peña and Mémbora 2013). While we were editing, FG made a draft of the frontispiece illustration, which the family reviewed and sent photos of a son to polish his visage. We also asked that the painting include the beautiful beaded necklace of two macaws that RIP had purchased when we travelled to Colombia together in 2016 to rep/matriate the digitized Wounaan stories: he wore it faithfully for congresses and ceremonial gatherings after that time. The final illustration was approved by the family on 7 November. In the illustration, the grayer colors of the background leaves imply death in their contrast with the bright, tropical ones throughout the book and they ascend skyward, as Wounaan do upon death (Figure 6). In the digital version of the book, this page will open with his flute 
playing, particularly the few notes he would play to call people to return to the congress meetings after a break.

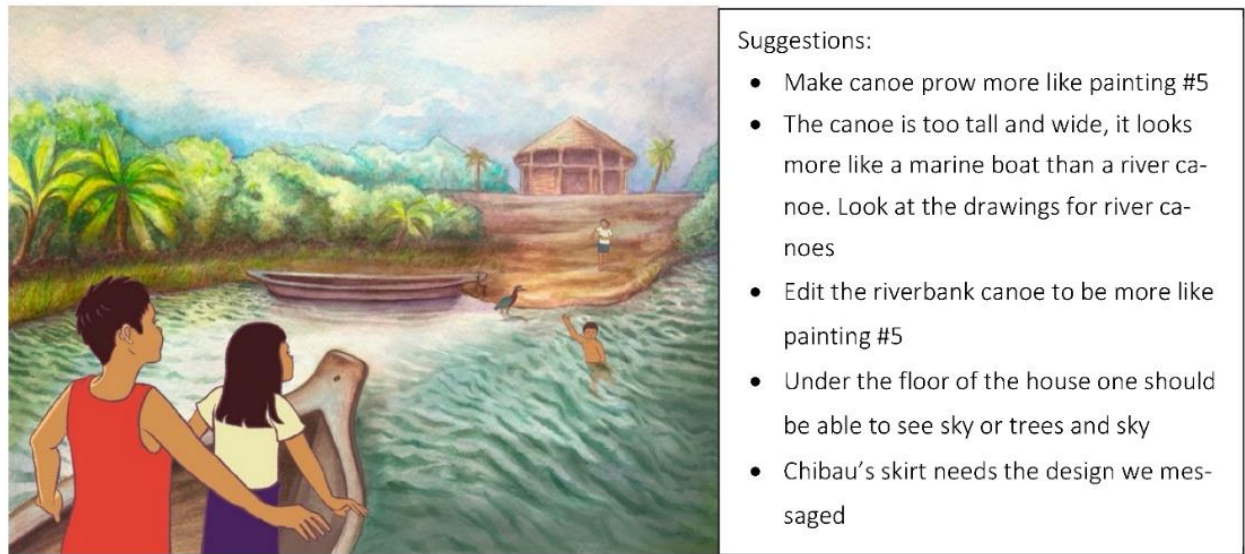

Figure 5. The book's first scene in October 2020. The suggested modifications are from a team video conference to review the first full draft of the paintings.

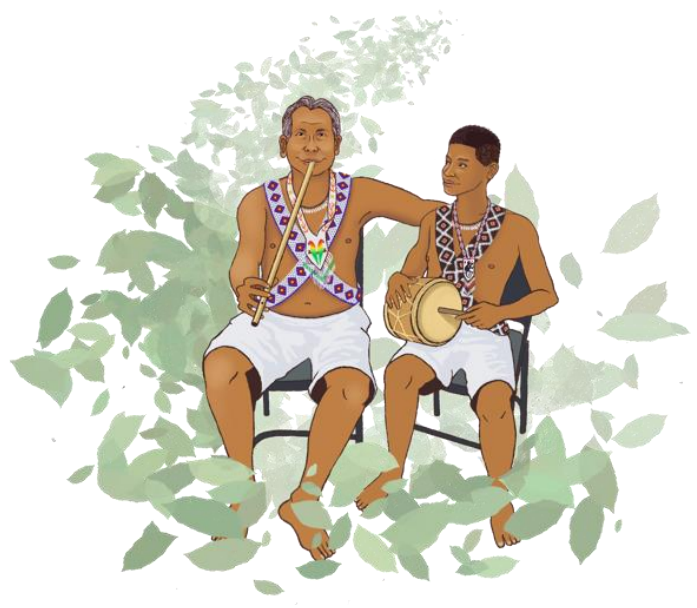

Figure 6. Frontispiece illustration of deceased colleague, co-author, pastor, flautist, previous national chief of the Wounaan people, and language and cultural expert hapk' $\Lambda \Lambda n$ Rito Ismare Peña with his son.

Our subsequent polishing rounds were crucial to making sure the narrative was clear and, after the penultimate paintings in late November, in line with them. Among the edits were "parents" instead of "parent" and gender parity. At times, the narrative was written as if it was occurring in the past rather than the present, which we revised to the present. In December, retired University of Panama historian and anthropologist Francisco Herrera (FH) edited the Spanish version of the narrative. He made a suggestion that the children's names be kept in Wounaan meu rather than somewhat awkward translations of them. The children's names were K'õsi and Chibau, which RIP and DCM had translated to Cariño (Dear), for the brother, and Blanca (White), for the sister. FH noted that the names could be ridiculed if translated. We addressed this and agreed that translating the names into Spanish did not adequately relay their meaning in Wounaan meu. In addition, maintaining their names in Wounaan meu also allowed us to evade the literal translation of Chibau as white. JVR asked CPI to address Chibau as a Wounaan name, not one related to a colonial gaze of whiteness. He responded by saying: "it has no origins with the white race ... It is a name given to girls because of their skin color ... and they have grown up being called that." As CCO said "White is also a ritually significant color for Wounaan." We continued polishing and received a second pandemic grant extension. 
We continued meeting and messaging to polish the images. In January, JVR paid for the more extensive edits to scene two, as between its original draft, the man to whom the children had been talking was left out of the scene. This made no sense given the story and FG added him to the painting, which was challenging given the geometry by which she had made the near final version. For the book audio, CCO, DCM, CPI, and DMP decided that rather than having any one of them read the book, they each would read a section. This decision brings forth Wounaan egalitarianism and relationality into the audio. Willow Older kindly revised the English literal translation to make it more of a free translation that would be readable by children. She made some helpful changes to the fluidity of the English, particularly with culturally complex scenes, such as the naveling one and the ancestral story at the end about how Wounaan obtained fire. She had removed much of the repetition, so JVR added much back in to be faithful to the Wounaan meu.

In March, 2021, CCO, JVR, and FG co-presented about the book development at the Symposium on Indigenous Languages of Latin America. DCM and DMP were to have joined as well, but two scheduling changes prevented their participation. CPI elected not to present and joined us at the end to respond to questions. We began the talk using photos to acknowledge the many people involved in the book's development, not just the authors and illustrator, but also colleagues that helped make early story decisions (chief Diogracio Puchicama Membache and FUNDEPW president Novel Carpio Mepaquito), to explain ideas or be sounding boards (MK), to suggest and support technology (Emily McGinn), and to polish translations (Francisco Herrera, Willow Older, and Liz Green). We also addressed how the project was possible because of years of cultural and linguistic work, originating with missionaries who trained an older generation of Wounaan writers, to the Wounaan Oral Traditions Project that focused on stories and supporting women in language and cultural expertise, and decades of work using Indigenous and community-based research ethics. The presentation was the first time FG made explicit the many artistic decisions she made for the book, including her thoughtful incorporation of movement, the same design style for birds and people given their relationship in ancestral stories, and the less controlled use of watercolor to highlight the importance and fluidity of water and rivers (Figure 7). In summarizing her decisions, she made three points:

"In an anthropological/cross-cultural setting, a successful illustrator should ... consider language carefully when applying design choices to faithfully represent the subject of the artwork. Artwork can be a universal form of language that should emphasize the 'focal points' of the subject and the overall message. Artwork can excite a curious audience and even serve as a powerful 'call to action' based on the focal points of the artwork's message."

We fielded questions about the book development. CPI clarified that in storytelling some words also are used to determine who is speaking, which the team changed into quotation marks for this written form. He also addressed the use of repetition, but noted that some was maintained in the illustrated story book, but not as much as an ancestral story. CCO talked about the importance of meeting community needs and the contest to find an illustrator who could work with the tight timeline. 

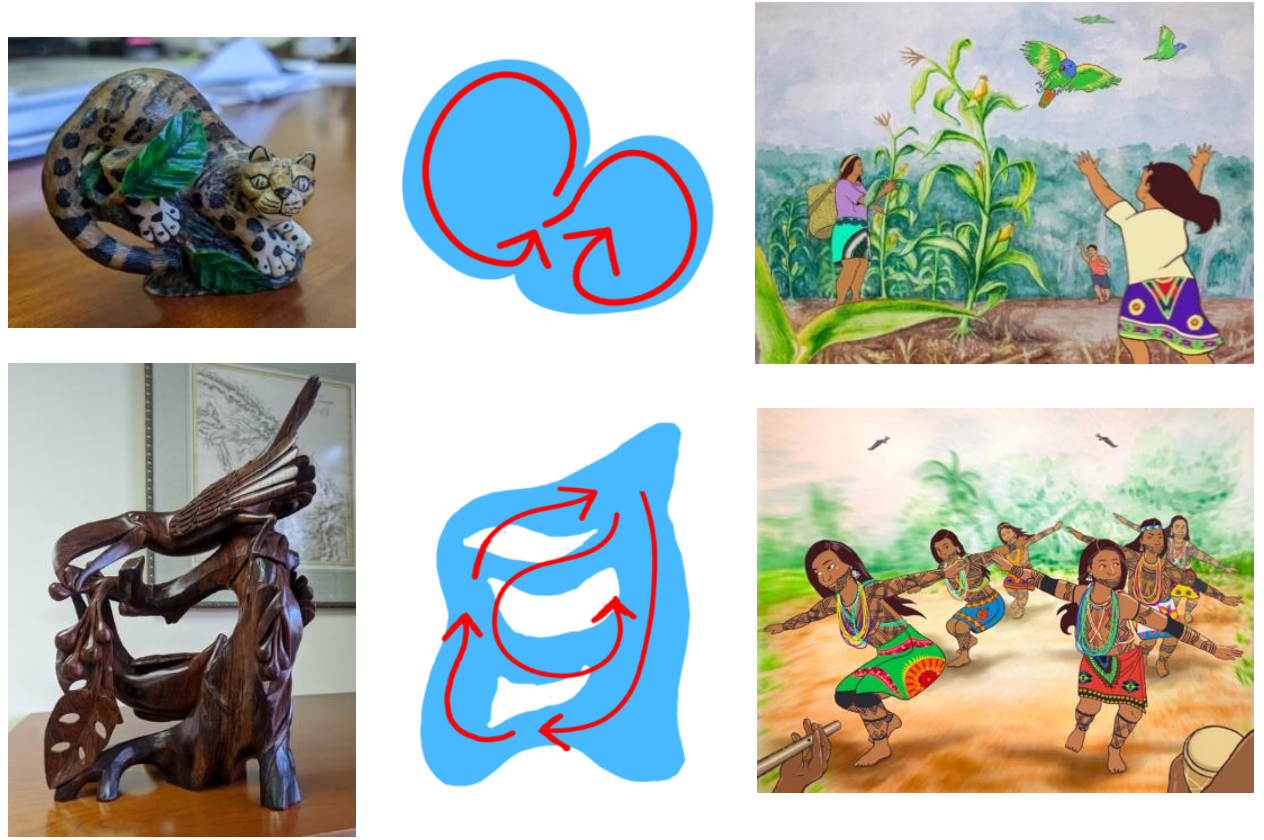

Figure 7. Movement in Wounaan art inspired the illustrations. (Top): The action of the characters is the focal point. Tagua carving by Eloy Membora, and design sketch and painting by Frankie Grin. (Bottom): The use of rhythm and space emphasizes the lines of dancers as the focal point and leads to the vultures flying overhead. Cocobolo carving by Alido Membache Donisabe, design sketch and painting by Frankie Grin.

We did three additional rounds polishing the story and its illustrations and checked the translations. We also received a third extension. With the additional work and stresses of the pandemic, it has been impossible for the team to be together for the close work of reviewing the story and the paintings together. Now that Panama is in a new phase of reopening, CCO, DCM, and DMP got together for a round of revisions. JVR, DCM, and DMP met to finalize them and JVR and CCO met again to review the changes when he had an internet connection again. Our work together allowed us to better see when the Wounaan meu narrative and illustrations did not align. In the vulture dance scene, the story had men and women dancing, but the painting had only women dancing. Both men and women dance; however, the Panama City dance group that is invited to performances comprises only women and might erroneously give the impression that only women dance. It was easier for FG to illustrate women because she had a video of Panama City's all women dance groups. As a result, we edited the narrative to mention both men and women dancing together, and then that a group of all women had taken a turn dancing. We also decided that the illustration needed to picture at least a little of a flute and drum, because the music imitates the birds' character and allows people to participate in the dance via sound. Another important edit was to move the ö̈ig $^{\mathrm{W}}$, the notched entry log, to the river side of the house, which would be its main entry point. CCO also asked to change the face of one man, noting that he still did not look Wounaan. After a couple of rounds of prompting by JVR as to why and promises to send FG more photos of men, CCO said "we original people have faces that are almost a little round, the eyebrows could be lower, and also straight hair." Additionally, as we began the final process of preparing the book for publication, we made sure to name some of the adults and to alternate actors and speakers among genders throughout the story. The project, with savings as a result of the pandemic, also agreed to pay FG to make the final changes to the illustrations, such as making the soil darker, the river sand lighter, adjusting the placement of the logs in the hearths, changing the color of the fish, and opening the grandfather's eyes a bit. JVR did another review and found some inconsistencies between the text in the three languages. The most critical was the scene where the father counsels the children on Wounaan land and caring for birds. 
He also said that with land Wounaan have language and their most important ceremony, haahi jëeu $n \Lambda m^{\mathrm{W}}$. That ceremony had been glossed in Spanish and subsequently English as "religiocity" and JVR changed it to name the ceremony for communication with the Creator, Hẽwandam ${ }^{\mathrm{W}}$ using the $k^{\prime} u g$ wiu prayer/petition canoe. CCO, DCM, and DMP met again for the final polishing round and JVR entered the corrections.

One of the surprisingly difficult tasks for us had been how to translate the book title into Spanish and English. The Wounaan meu title, Wounaan chaain döhigaau nemchaain hoo wënsırrajim, includes the spatial action of going upriver/into forests and seeing birds with that movement. DCM, DMP, and CCO translated the title into Spanish, Los niños wounaan, en su aventura vieron muchas aves. In English, however, we could not come up with a concise title that did justice to the spatiality and action of the Wounaan meu: we have tentatively titled it as The Adventures of Wounaan Children and Many Birds. Rather than a single book with the three languages, we decided to print the book in each of the three languages, so the text could be in a large font size for children to read.

Our remaining work is to upload the corrected files, finalize the audio for the digital book, and send the book to be printed. CCO, DCM, and DMO also brainstormed the storying, thinking through the narrative to prepare the verbal storytelling for audio recording. Some music, bird songs or calls were already in the story, and we considered auditory elements for the audio recording of the storying, such as the abdominal pulses for emphasis and the sounds of people and environment together. Finally, we decided to print the book in Panama so that profits from sales would accrue to the Wounaan Podpa N $\Lambda$ m Pömaam and Foundation for the Development of Wounaan People. We are uploading the illustrations and the text in the three languages onto the StoryJumper platform, which allows free viewing and easy print on demand for international sales. We must finalize the book within the month.

\section{Conclusions}

"At one time people shared, shared what they had with others. That was very natural in all people. If I had it, and it was enough for someone else, I would give it. If another had it, and it was enough for me, s/he shared with me ... that good habit, of sharing, of the beauty of Wounaan life, how to live as a brotherhood, as a sincere brother, even with unknown people, that beautiful part that existed, no longer exists ... because pä kër ${ }^{\mathrm{W}}$ or mal oficio ${ }^{S}$ [plant-based poisoning] is so close [when people are out of community] ... " Chindío Peña Ismare, September 2021.

In this article, we tell the story of our storying of the illustrated story book Wounaan chaain döhigaau nemchaain hoo wën s.rrajim. We developed a story based on Wounaan stories to value and honor the relational conviviality of Wounaan life and landscapes, of which birds are just a part. Through our shared commitment to Indigenous revitalization and resurgence, we crafted the illustrated story book as an anticolonial intervention, providing Wounaan children materials in their language that visually and audially celebrate Wounaan lifeworlds and stories. We recognized that with beautiful illustrations and through new digital media we could create a multimodal work, one that is available in-print to those who pay for it and free by smart phone. The digital version also allowed us to revere verbal storying, to incorporate the telling and crafting of stories in the audio, together with sounds and music. This has enabled us to harness some of the promise of new media and orient it to knowledge practice as future orientation, as part of Indigenous futurisms that are beyond an emphasis on video (Corwin 2016; Fricke 2017; Ginsburg 1994; Hirschkind et al. 2017; Srinivasan 2006). It recognizes that digital technologies may resemble and even parallel Indigenous means of producing and sharing knowledge and of experiencing time and space, reminiscent of Howe's (1999) idea of tribalography on the augmentation of knowledge through sharing stories and experiences (de la Garza 2016; Howe 1999). It was challenging, particularly as we worked remotely during the pandemic, to weave and polish emplaced, multisensorial Wounaan lifeworlds. This is a challenge we are taking up in other work. 
In writing about our storying, we likewise worked to respect that complexity, showing not only the many intentional decisions about conviviality, knowing/doing, egalitarianism, time, ancestors, space, rivers, land rights, beauty, and movement, but also how our Indigenous collaborative and storywork method of weaving and polishing is embodied care and redistributive practice, allowing us to return again and again to strengthen the work for future generations. Beyond the recent scholarly attention to slow scholarship (e.g., Mountz et al. 2015) or communities of practice (e.g., Lave and Wenger 1991), we have approached this as embodied Indigenous method. Ours is a method learned by being in community, respecting each other's embodied, emplaced knowledge, and being attentive to redistributive care and land education (Archibald 2008; Carpio Opua and Velásquez Runk 2013; Denzin et al. 2008; Kimmerer 2013; McCoy et al. 2016; Simpson 2017; Smith 2002; Velásquez Runk 2014; Windchief and Pedro 2019). It is informed by a recognition of settler colonialism and resistance to domination, by the experiential that is theoretical (Simpson 2017, Martinez this volume). It is convivial caretaking as Indigenous method, community based or community driven, in which Wounaan knowing and doing are foundational and sovereign. As CPI summarized:

"One of the things that the authors wanted to emphasize in this book is in relation of animals to environment, in this case, mainly birds. In one of the scenes where the father is going downriver talking with his children he told them that he had to treat animals well, that they have to be cared for because in the Wounaan concept, and I think that of many Indigenous cultures, people coexist with animals. And both serve each other. In that sense, I believe that the emphasis is on taking care of animals and not mistreating them and also teaching others, our children, that we must take care of animals, we must love them, we must like them. Because they, like people, feel, eat, and also die. But they die naturally many times and should not be destroyed. I think one of the messages was that."

Much as the Wounaan meu verb " $k$ 'oss $h a^{\mathrm{W}}$," to love or to care, adorns the male protagonist's name, convivial care is foundational to the book. It is through lengthy, careful, intentional community-based collaboration and storywork that we celebrate Wounaan lifeworlds and intervene on colonial knowledge practice. Constrained by time, resources, and sorrow, we also have co-labored to write and visualize the joy and beauty of Wounaan lifeworlds, in which the past is in the present and in the future.

Author Contributions: Conceptualization, R.I.P., C.C.O., D.C.M., F.G., D.M.P., C.P.I., J.V.R.; methodology, R.I.P., C.C.O., D.C.M., F.G., C.P.I., J.V.R.; validation, R.I.P., C.C.O., D.C.M., D.M.P., C.P.I., J.V.R.; investigation, R.I.P., C.C.O., D.C.M., J.V.R.; resources, C.C.O., J.V.R.; data curation, C.C.O., J.V.R.; writing—original draft preparation, J.V.R.; writing—review and editing, R.I.P., C.C.O., D.C.M., F.G., D.M.P., C.P.I., J.V.R.; visualization, F.G.; supervision, C.C.O., J.V.R.; project administration, C.C.O., J.V.R.; funding acquisition, C.C.O., J.V.R. All authors have read and agreed to the published version of the manuscript.

Funding: This research was funded by the Small Grants Program of the United Nations Development Program and the Global Environment Facility.

Institutional Review Board Statement: This research was approved by the authorities of the Wounaan Podpa Nım Pömaam and the Fundación para el Desarrollo del Pueblo Wounaan. The study was conducted according to the guidelines of the Declaration of Helsinki, and approved by Panama's Instituto Nacional de Cultura under Resolución 004-2018 on 8 January 2018 and The Smithsonian Institution Institutional Review Board under protocol code HS18008 on 26 December 2017. The University of Georgia Institutional Review Board gave this study an exempt determination under protocol code 05616 on 17 December 2017.

Informed Consent Statement: Informed consent was obtained from all subjects involved in the study.

Data Availability Statement: Data sharing not applicable.

Acknowledgments: We are thankful to the elected authorities of Panama's Wounaan Podpa Nım Pömaam (WPNP) and the Fundación para el Desarrollo del Pueblo Wounaan (FUNDEPW), who together with the Wounaan communities of Puerto Lara, Río Hondo, and Río Platanares hosted the two projects through which we got to converse, walk, and bird about Wounaan lifeworlds, 
ultimately leading to the illustrated story book. To develop the book, we appreciated the counsel of Diogracio Puchicama Peña, National Chief of the WPNP, and Novel Carpio Mepaquito, President of the FUNDEPW, and that also of Marsha Kellogg, Executive Director of Native Future. Digital support was provided by Emily McGinn, Director of the UGA Digital Humanities Lab, and Guthrie Armstrong. Spanish polishing was by Francisco Herrera and English polishing by Willow Older. We were appreciative of Liz Green's kind offer to interpret for several video conferences. We are grateful for Felice Wyndham's invitation to join other research teams working on birds with Indigenous communities at the 2018 International Congress of Ethnobiology, thanks to a British Academy Knowledge Frontiers' grant in 2018. JVR thanks a 2018-2019 National Endowment for the Humanities Fellowship at the National Humanities Center and a 2019 UGA Willson Center Faculty Fellowship during which she completed some of this work. We also are appreciative of the storywork that preceded this, particularly that of the 2009-2013 Wounaan Oral Traditions Project, funded by the National Science Foundation, BCS 0966520 and 0966046 . This manuscript was greatly improved thanks to the helpful suggestions of two anonymous peer reviewers, Jamie Haverkamp, Kasey Jernigan, Marsha Kellogg, Doreen Martínez, Emily McGinn, and Darren Ranco. JVR also thanks Felice, Mònica Martínez Mauri, and David Hecht for conversations about people and birds. Н̈̈и hajim, k'apeen.

Conflicts of Interest: The authors declare no conflict of interest.

\section{Note}

1 Hapk' $\Lambda \Lambda n$ is one of many honorifics in Wounaan meu for the deceased. We decided that our deceased friend and colleague should be lead author of this article, with the remaining authors listed in alphabetical order.

\section{References}

Archibald Q'um Q'um Xiiem, Jo-Ann, Jenny Boi Jun Lee-Morgan, and Jason De Santolo, eds. 2008. Decolonizing Research: Indigenous Storywork as Methodology. London: Zed Books.

Archibald, Jo-Ann. 2008. Indigenous Storywork: Educating the Heart, Mind, Body, and Spirit. Vancouver: University of British Columbia Press.

Arias, Arturo. 2018. From indigenous literatures to Native American and Indigenous theorists: The makings of a grassroots decoloniality. Latin American Research Review 53: 613-26. [CrossRef]

Binder, Reinaldo, Chenier Carpio Opua, Doris Cheucarama Membache, B. Gordon, Elizabeth Lapovsky Kennedy, Chivio Membora Peña, Tonny Membora Peña, Toño Peña Conquista, Chindío Peña Ismare, and Julie Velásquez Runk. 2013. Traducir conceptos difíciles en wounaan meu: Experiencias en transcribir y traducir tradiciones orales wounaan. Paper present at Congreso de Antropología de Panamá, Panama City, Panama, September 6.

Binder, Ronald, Chenier Carpio Opua, Doris Cheucarama Membache, B. Gordon, Elizabeth Kennedy, Chivio Membora Peña, Tonny Membora Peña, Toño Peña Conquista, Chindío Peña Ismare, and Julie Velásquez Runk. 2015. A cross-model, multi-genre description of the Wounaan meu demonstrative system. Paper present at Society for the Study of Indigenous Languages of the Americas, Portland, OR, USA, January 8-11.

Binder, Ronald, Phillip Lee Harms, Chindío Peña Ismare, and Chafil Cheucarama M. 1978. Vocabulario Ilustrado: Wounmeu, Español, epena Pedee, 1st ed. Santafé de Bogotá: Asociación Instituto Linguistico de Verano.

Cajete, Gregory. 2000. Native Science: Natural Laws of Interdependence. Santa Fe: Clear Light Publishers.

Carpio Opua, Chenier, and Julie Velásquez Runk. 2013. El proceso de colaboración en un proyecto para documentar el idioma wounaan meu. Paper present at Congreso de Antropología de Panamá, Panama City, Panama, September 6.

Carpio Opua, Chenier, Doris Cheucarama Membache, Chivio Membora Peña, Tonny Membora Peña, Toño Peña Conquista, Chindío Peña Ismare, and Julie Velásquez Runk. 2015. Proyecto Tradición Oral Wounaan. Paper present at Charlas al Público del Smithsonian Tropical Research Institute, Panama City, Panama, June 26.

Carpio Opua, Chenier, Doris Cheucarama Membache, Elizabeth Lapovsky Kennedy, Chivio Membora Peña, Tonny Membora Peña, Toño Peña Conquista, Chindío Peña Ismare, and Julie Velásquez Runk. 2013. Analisis incial de los cambios sociolingüísticos en echar cuentos wounaan. Paper present at Congreso de Antropología de Panamá, Panama City, Panama, September 6.

Cheucarama, Manelio, and Alcides Chamarra. 1977. Jöoingarm Nem Higk'aa, Tomo1. Edited by Reinaldo Binder and Toño Peña. Panamá: Instituto Lingüístico de Verano.

Clarke, Philip A. 2016. Birds and the spirit world of the Lower Murray, South Australia. Journal of Ethnobiology 36: 746-64. [CrossRef] Constenla Umaña, Adolfo. 1991. Las lenguas del Area Intermedia: Introducción a su Estudio Areal. San Jose: Editorial de la Universidad de Costa Rica.

Corntassel, Jeff. 2009. Indigenous storytelling, truth-telling, and community approaches to reconciliation. ESC: English Studies in Canada 35: 137-59. [CrossRef]

Corwin, Jason N. 2016. Indigenous Ways of Knowing, Digital Storytelling, and Environmental Learning-A Confluence of Tradition and New Media Technology. Ph.D. thesis, Cornell University, Ithaca, NY, USA. 
Daly, Nicola. 2019. The linguistic landscape of multilingual picturebooks. Linguistic Landscape 53: 281-301. [CrossRef] de Freitas, Maria Niely, and Maria Corette Pasa. 2011. En-Canto: A Etno-Ornitología no Sul de Mato Grosso. Jundiaí: Paco Editorial. de la Garza, Armida. 2016. Aboriginal digitalities: Indigenous peoples and new media. In The Digital Arts and Humanities. Edited by Charles Travis and Alexander von Lünen. Cham: Springer International Publishing, pp. 49-62.

Denzin, Norman K., Yvonne S. Lincoln, and Linda Tuhiwai Smith. 2008. Handbook of Critical and Indigenous Methodologies. Thousand Oaks: SAGE Publications.

Díaz, Floriberto. 2007. Escrito. Comunalidad Energía Viva del Pensamieno Mixe. Ayuujktsënää Yën-Ayuujkwënmää'ny-Ayuujk Mëk'äjtën. Edited by Sofia Robles Hernández and Rafael Cardoso Jiménez. Mexico City: Universidad Nacional Autónoma de México.

Diskin, Martin. 1963. Noanamá Society and Folktales. Master's thesis, University of California, Los Angeles, CA, USA.

Dorfman, Ariel. 1983. The Empire's Old Clothes: What the Lone Ranger, Babar, and Other Innocent Heroes Do to Our Minds. Durham: Duke University Press.

Dove, Michael R. 1993. Uncertainty, humility, and adaptation in the tropical forest: The agricultural augury. Ethnology 32: $145-67$. [CrossRef]

Equipo Cultural Wounaan. 2018a. Some Birds in Wounaan Culture. Panama City: Wounaan Pöpa Nım Pömaan.

Equipo Cultural Wounaan. 2018b. Algunas aves en la cultura wounaan. Panama City: Wounaan Pöpa Nım Pömaan.

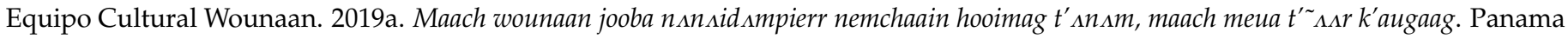
City: Wounaan Pöpa Nım Pömaan.

Equipo Cultural Wounaan. 2019b. Nemchaain Laraam, t' $1 n \wedge m$ k'aurtarrau. Panama City: Wounaan Pöpa Nım Pömaan.

Fricke, Suzanne Newman. 2017. Introduction: Indigenous futurisms in the hyperpresent now. World Art 9: 107-21. [CrossRef]

Ginsburg, Faye. 1994. Embedded aesthetics: Creating a discursive space for indigenous media. Cultural Anthropology 9: 365-82. [CrossRef]

Halbmayer, Ernst. 2019. Amerindian Sociocosmologies of Northwestern South America. Some Reflections on the Dead, Metamorphosis, and Religious Specialists. Journal of Latin American and Caribbean Anthropology 24: 13-31.

Halbmayer, Ernst. 2020. Introduction: Towards and anthropological understanding of the area between the Andes, Mesoamerica, and the Amazon. In Amerindian Socio-Cosmologies between the Andes, Amazonia and Mesoamerica: Towards an Anthropological Understanding of the Isthmo-Colombian Area. Edited by Ernst Halbmayer. New York: Routledge, pp. 3-34.

Hirschkind, Charles, Maria José A. de Abreu, and Carlo Caduff. 2017. New media, new publics? Current Anthropology 58: S3-S12. [CrossRef]

Howe, LeAnne. 1999. Tribalography: The Power of Native Stories. Journal of Dramatic Theory and Criticism XIV: 117-25.

Ibarra, José Tomás, and Cristóbal Pizarro. 2016. Hacia una etno-ornitología interdisciplinaria, intercultural e intergeneracinal para la conservación biocultural. Boletín Chileno de Ornitología 22: 1-6.

Ismare Peña, Rito, and Cárdenio Mémbora. 2013. Comunicado del IX Congresio Nacional Ordinario del Pueblo Wounaan. Panama City: Congreso Nacional del Pueblo Wounaan.

Ismare Peña, Rito, Doris Cheucarama Membache, and Julie Velásquez Runk. 2018. Las aves en la música y danza wounaan. Belém: International Society for Ethnobiology.

Ismare, Peña Rito, Doris Cheucarama Membache, and Julie Velásquez Runk. 2019. Las aves en la música y danza wounaan. Paper present at II Congreso de Antropología e Historia, Panama City, Panama, July 15.

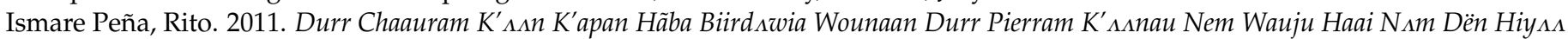
Hamau Nem. Panama City: Naciones Unidas Derechos Humanos.

Ismare, Gáligo. 1978. Warrgar Jöoin Do'keu Hee Narr. Panamá: Instituto Lingístico de Verano.

Justice, Daniel Heath. 2018. Why Indigenous Literatures Matter. Waterloo: Wilfrid Laurier University Press.

Kane, Stephanie. 2015. Bird names and folklore from the Emberá (Chocó) in Darién, Panamá. Ethnobiology Letters 6: 32-62. [CrossRef]

Kennedy, Liz Lapovsky, and Perry Kennedy. 2011. The Wounaan Trilogy: U.S.A. Available online: https://www.hallwalls.org/mediaarts/5899.html (accessed on 30 April 2021).

Kimmerer, Robin Wall. 2013. Braiding Sweetgrass: Indigenous Knowledge, Scientific Wisdom, and the Teachings of Plants. Minneapolis: Milkweed Editions.

Kirkness, Verna J., and Ray Barnhardt. 1991. First Nations and higher education: The four R's—Respect, relevance, reciprocty, and respnsibility. Journal of American Indian Education 30: 1015.

Köhler, Axel, Xochitl Leyva, Xuno López Intzín, Damián Guadalupe Martínez Martínez, Rie Watanabe, Juan Chawuk, José Alfredo Jiménez Pérez, Floriano Enrique Hernández Cruz, Mariano Estrada Aguilar, and Pedro Agripino Icó Bautista, eds. 2010. Sjalel Kibeltik. Sts' Isjel ja Kechtiki'. Tejiendo Nuestras Raíces. San Cristobál de las Casas: Universidad de Ciencias y Artes de Chiapas, Centro de Investigaciones y Estudios Superiores en Anthropología Social, Universidad Nacional Auónoma de México.

Kopenawa, Davi, and Bruce Albert. 2013. The Falling Sky. Cambridge: Harvard University Press.

Kovach, Margaret. 2009. Indigenous Methodologies: Characteristics, Conversations, and Contexts. Toronto: University of Toronto Press.

Kovach, Margaret. 2018. A story in the telling. LEARNing Landscapes 11: 49-54. [CrossRef]

Lapovsky Kennedy, Elizabeth. 1972. The Waunan of the Siguirisua River: A Study of Individual Autonomy and Social Responsibility with Special Reference to the Economic Aspects. Ph.D. thesis, University of Cambridge, Cambridge, UK.

Lave, Jean, and Etienne Wenger. 1991. Situated Learning: Legitimate Peripheral Participation. Cambridge: Cambridge University Press. 
Leyva, Xochitl, and Shannon Speed. 2015. Hacia la investigación descolonizada: Nuestra experiencia de co-labor. In Prácticas Otras de Conocimiento (s): Entre Crisis, Entre Guerras. Edited by Xóchitl Leyva, Alsonso Jorge, R. Aída Hernández, Arturo Escobar, Axel Köhler, Aura Cumes, Rafael Sandoval, Shannon Speed, Mario Blaser, Esteban Krotz and et al. San Cristóbal de Las Casas: Cooperativa Retos.

Loewen, Jacob A. 1961. Good news for the Waunana. Practical Anthropology 8: 275-78. [CrossRef]

Lotero Villa, Luz. 1972. Monografía de los Indígenas Noanamá: Tribu de una Región Colombiana. Medellín: Coltejer, p. 294.

Martínez Mauri, Mónica, George Angehr, Daniel Buitrago-Rosas, Euclides Campos, Igua Jiménez, and Grupo Wagibler. 2014. Una Guía Ornitológica y Cultural a las Aves de Gunayala. Panama City: Editora Novo Art, S.A. [CrossRef]

Mathis Pitts, Kimberly, Analuisa Alvarado, and Gladys Teos de Molina. 2019. The Magical Skies of Sumpango. Los Cielos Mágicos de Sumpango. Guatemala Series; Lansing: Vistra Tranquila Publishers.

McCoy, Kate, Eve Tuck, and Marcia McKenzie, eds. 2016. Land Education: Rethinking Pedagogies of Place from Indigenous, Postcolonial, and Decolonizing Perspectives. Oxofrdshire: Routledge.

Medrano, Celeste, Fernando Zamudio, and Javier Lopez de Casenave. 2017. Etno-ornithología: Una ciencia que todos saben. Hornero 32: $1-6$.

Medrano, Celeste. 2017. Ornito-sociocosmología quom o las aves en la vida de los tobas. Hornero 32: 165-78.

Micarelli, Giovanna. 2018. Investigar en un mundo encantado: Los aportes de las metodologías indígenas al quehacer etnográfico. Unidersitas Humanísticas, 219-45. [CrossRef]

Mountz, Alison, Anne Bonds, Becky Mansfield, Jenna Loyd, Jennifer Hyndman, Margaret Walton-Robert, Ranu Basu, Risa Whitson, Roberta Hawkins, Trina Hamilton, and et al. 2015. For slow scholarship: A feminist politics of resistance through collective action in the neoliberal university. ACME: An International Journal for Critical Geographies 14: 1235-59.

Moutinho, Sofia. 2021. How One Man-and a Creative Map-Made a Difference in Panama's COVID-19 Crisis. Available online: https: //www.npr.org/sections/goatsandsoda/2021/04/06/982708354/the-mapmaker-whos-saving-lives-in-panamas-pandemic (accessed on 30 April 2021).

Mecha, Manuel Críspulo Moya, and Adriana Sanín Escobar. 1998. Cuéntelos Bien Como yo le Conté: Cuentos Emberá, 1a ed. Medellín: Editorial Universidad de Antioquia.

Ojeda, Ana Paula, and Juan Palomino. 2011. Jaguar, "Corazon de la Montaña". Mexico City: Conaculta and Ediciones Tecolote.

Olalde Ramos, Guadalupe. 1996. Contar y recontar: Aproximación al análisis de recursos estilísticos en la narrativa tzotzil. Chiapas: Gobierno del Estado de Chiapas/Universidad de Ciencias y Artes de Chiapas.

Osorio Chiripua, Hector, J. Velásquez Runk, Franscisco Herrera, and Olivia Ferrari. 2020. Una Guia Wounaan Para la Reforestación. Panama City: Wounaan Podpa Nım Pömaam and Fundación para el Desarrollo del Pueblo Wounaan.

Peña Ismare, Chindío, J. Velásquez Runk, Rito Ismare Peña, and Chenier Carpio Opua. 2020. The Wounaan haaihí jeeu nım ritual with the k'ugwiu: Reinforcing benevolence and preventing calamity. In Amerindian Socio-Cosmologies between the Andes, Amazonia, and Mesoamerica: Towards an Anthropological Understanding of the Isthmo-Colombian Area. Edited by Ernst Halbmayer. Oxfordshire: Routledge Press.

Peña Ismare, Chindío, Rito Ismare Peña, Chindío Carpio Opua, and Julie Velásquez Runk. 2019. El ritual wounaan de haaihí jeeu nım con el k’ugwiu. In II Congreso de Antropología e Historia. Ciudad de Panamá: Publisher.

Peña Ismare, Chindío. 1997. Maach Wounaanau Nem Sirnaa Hau nım dıi Jemk'a Nımpa K'ĩirpierr (La Musica de los Wounaan y las Ceremonias Asociadas con Cada Estilo). Edited by Reinaldo Binder. Panamá: Iglesia Evangélica Unida.

Peña Ismare, Chindío. 2006. Pueblos indígenas: Wounaan y la cultura nacional. Cuadernos Nacionales 10: 66-87.

Peña Ismare, Chindío. 2007. Historica, cultura, y tradiciones del pueblo Wounaan: ¿quienes son los Wounaan, de dónde salieron? Cuadernos Nacionales 3: 66-87.

Peña, Chindío, and Rito Ismare. 2007. Hewandamag Meuk'aar Haaujem. Edited by Reinaldo Binder. Panamá: Iglesia Evangélica Unida.

Peña, Chindío, Gáligo Ismare, and y otros. 1987. Hewandam Hiek. Edited by Reinaldo Binder. Panamá: Sociedad Bíblica.

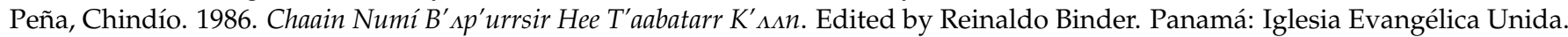

Peña, Chindío. 2009. El Mundo de los Wounaan: Categorias de Vocabulario y Perspectivas Culturales. Edited by Reinaldo Binder. Panamá: Iglesia Evangélica Unida.

Peña, Tono, and Chindio Peña. 1986. Maach Meua Hesapdau K'augtarrau, Libro 2. Edited by Reinaldo Binder. Panamá: Iglesia Evangélica Unida.

Peña, Toño. 1989. Maach Meúa Hesapdau K'augtarrau. Edited by Reinaldo Binder. Panamá: Instituto Lingüístico de Verano.

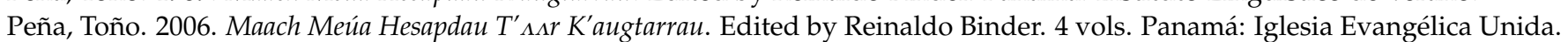

Perry, Keisha-Khan Y., and Joanne Rappaport. 2013. Making a case for collaborative research with black and indigenous social movements in Latin America. In Otros Saberes. Collaborative Research on Indigenous and Afro-Descendant Cultural Politics. Edited by Charles R. Hale and Lynn Stephen. Santa Fe: School for Advanced Resesarch, pp. 30-48.

Ramos, Alcida Rita. 2019. Metodologia. Nem contra, nem a favor, muti pelo contrario. Cuandernos de Antropología Social 50: 21-31.

Reichel-Dolmatoff, Gerardo. 1962. Contribuciones a la etnografía de los indios chocó. Revista Colombia de Antropología XI: 169-88.

Rocha Vivas, Miguel. 2013. Palabras Mayores, Palabras Vivas: Tradiciones Míticos-Literarias y Escritores Indígenas en Colombia. Bogotá: Penguin Random House Grupo Editorial Colombia.

Rocha-Buelvas, Anderson, and Rodrigo Ruíz-Lurduy. 2018. Agendas de investigación indígena y decolonialidad. Izquierdas 41: 187-97. [CrossRef] 
Sarmiento, Fausto O. 2010. The lapwing in Andean ethnoecology: Proxy for landscape transformation. Geographical Review 100: $229-45$. [CrossRef]

Sault, Nicole. 2020. Bird stories from Latin America: Lessons on change and adaptation. Ethnobiology Letters 11: 58-68. [CrossRef]

Serrano Echeverría, Julio, and Marielle Che-Novak. 2018. Desde Las Aguas. Altos de San Carlos: Amanuense.

Sherzer, Joel. 2003. Stories, Myths, Chants, and Songs of the Kuna Indians. Austin: University of Texas Press.

Simon, Scott. 2020. A little bird told me: Changing human-bird relations on a Formosan indigenous territory. Anthropologica 62: 70-84. [CrossRef]

Simpson, Leanne Betasamosake. 2017. As We Have Always Done: Indigenous Freedom Through Radical Resistance. Minneapolis: University of Minnesota Press.

Smith, Linda Tuhiwai. 2002. Decolozing Methodologies: Research and Indigenous Peoples. London: Zed Books.

Srinivasan, Ramesh. 2006. Indigenous, ethnic and cultural articulations of new media. International Journal of Cultural Studies 9: 497-518. [CrossRef]

Taggart, James A. 1986. "Hansel and Gretel” in Spain and Mexico. The Journal of American Folklore 99: 435-60. [CrossRef]

Tidemann, Sonia, and Andrew Gosler. 2010. Ethno-Ornithology: Birds, Indigenous Peoples, Culture and Society. Washington, D.C.: Earthscan.

Uzendowski, Michael A. 2012. Beyond orality: Textuality, territory, and ontology among Amazonian peoples. HAU: Journal fo Ethnographic Theory 2: 55-80. [CrossRef]

Vásquez-Dávila, Marco Antonio. 2014. Aves, Personas y Culturas: Estudios de Etno-Ornitología. Oaxaca: CONACYT, ITVO, Carteles Editores, UTCH.

Velásquez Runk, J., and Chenier Carpio Opua. 2018. The collaborative process in a Wounaan meu language documentation project. In Insights from Practices in Community-Based Research: From Theory to Practice Around the Globe. Edited by Shannon T. Bischoff and Carmen Jany. Berlin: De Bruyter Mouton, pp. 246-65.

Velásquez Runk, J., Chindío Peña Ismare, and Toño Peña Conquista. 2019a. Animal transferance and transformation among Wounaan. Journal of Latin American and Caribbean Anthropology 24: 32-51. [CrossRef]

Velásquez Runk, Julie, Toño Peña Conquista, and Chindío Peña Ismare. 2016. Transferencia de y transformación a animales entre wounaan. Paper present at I Congreso de Antropología e Historia de Panamá, Panama City, Panama, September 7-9.

Velásquez Runk, Julie, Chenier Carpio Opua, Doris Cheucarama Membache, and Rito Ismare Peña. 2019b. From indigenous Wounaan schoolchildren to bird-watching tourists: Meeting community and donor interests in community-based ethno-ornithology projects. Paper present at Intersections of Language and Nature Conference, Pittsburgh, PA, USA, September 6-7.

Velásquez Runk, Julie, Linda Kosen, Francisco Herrera, and Marsha Kellogg. 2020. Evite la Enfermedad, Protega la Comunidad. Athens: Self-Published.

Velásquez Runk, Julie. 2012. Indigenous land and environmental conflicts in Panama: Neoliberal multiculturalism, changing legislation, and human rights. Journal of Latin American Geography 11: 21-47. [CrossRef]

Velásquez Runk, Julie. 2014. Enriching indigenous knowledge scholarship via collaborative methodologies: Beyond the high tide's few hours. Ecology and Society 19: 37. [CrossRef]

Velásquez Runk, Julie. 2017. Crafting Wounaan Landscapes: Art, Identity, and Environmental Governance in Panama's Darien. Tucson: University of Arizona Press.

Velásquez Runk, Julie. 2020a. Decolonizing more-than-human scholarship, building collaboration. LASA Foum 51: 94-98.

Velásquez Runk, Julie. 2020b. Intercambio, cuidado y ser humano: Chamismo y el ritual haaihí jeeu nım entre los wounaan de Panamá. Tabula Rasa 36: 151-76. [CrossRef]

Ventocilla, Jorge. 2020. Un colectivo y dos conversatorios, para conocernos mejor. La Estrella de Panamá, October 11.

Wassén, Henry. 1933. Cuentos de los indios Chocós recogido por Erland Nordenskiold durante su expedición al istmo de Panamá en 1927 y publicados con notas y observaciones comparativas de Henry Wassén. Journal de la Societé des Américanistes XXV: 105-37.

Wassén, Henry. 1963. Estudios chocoes; Etnohistoria chocoana y cinco cuentos waunana apuntados en 1955. Etnologiska Studier 26: $1-78$.

Watts, Vanessa. 2013. Indigenous place-thought \& agency amongst humans and non-humans (First Woman and Sky Woman go on a European world tour!). Decolonization: Indigeneity, Education E Society 2: 20-34.

WHO. 2021. Archived: WHO Timeline-COVID-19. Available online: https://www.who.int/news/item/27-04-2020-who-timeline--covid-19 (accessed on 30 April 2021).

Wilson, Shawn. 2008. Research Is Ceremony: Indigenous Research Methods. Black Point: Fernwood Publishing.

Windchief, Sweeney, and Timothy San Pedro. 2019. Applying Indigenous Research Methods: Storying with Peoples and Communities. New York: Routledge.

Woskie, Liana, and Clare Wenham. 2021. Do men and women "lockdown" differently? Examining Panama's Covid-19 sex-segregated social distancing policy. Feminist Economics 27: 327-44. [CrossRef]

Wyndham, Felice S., and Karen E. Park. 2018. "Listen carefully to the voices of the birds": A comparative review of birds as signs. Journal of Ethnobiology 38: 533-49. [CrossRef] 